\title{
STUDI KEBIJAKAN PENGIKUTSERTAAN ORANG TUA TERHADAP PENINGKATAN MUTU PENDIDIKAN DI SDN SONGGOKERTO 3 KOTA BATU
}

\section{TESIS}

Untuk Memenuhi Sebagian Persyaratan

Memperoleh Derajat Gelar S-2

Program Studi Magister Kebijakan dan Pengembangan Pendidikan

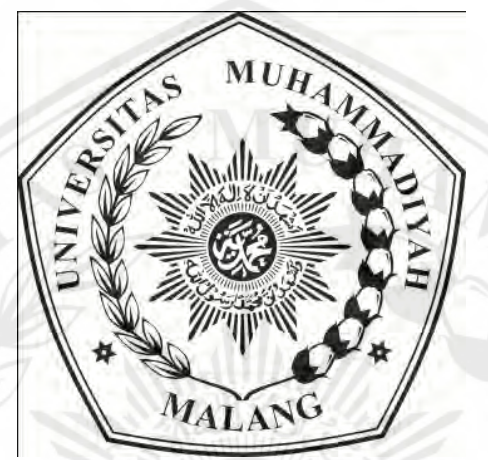

Disusun oleh :

MAULIDIN ARDIYANSYAH W.P

NIM : 201710240211014

DIREKTORAT PROGRAM PASCASARJANA

UNIVERSITAS MUHAMMADIYAH MALANG

Maret 2019 


\section{STUDI KEBIJAKAN PENGIKUTSERTAAN ORANGTUA TERHADAP PENINGKATAN MUTU PENDIDIKAN DI SDN SONGGOKERTO 3 KOTA BATU}

\section{MAULIDIN ARDIYANSYAH W.P 201710240211014}

\section{Telah disetujui}

Pada Hari/tanggal, Kamis 28 Maret 2019

Pembimbing Utama

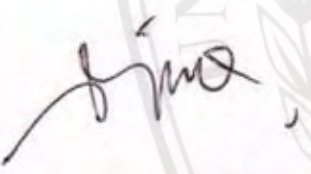

Dr. Ahmad Juanda

Direktur Program Pascasarjana

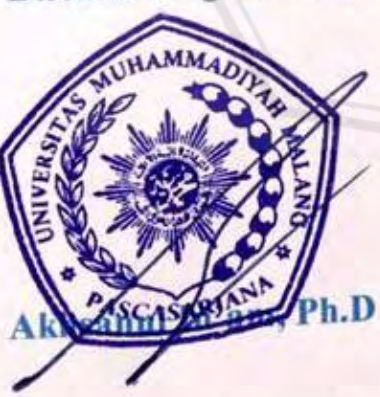

Pembimbing Pendamping

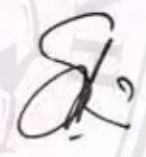

Dr. Mohamad Syahri

Ketua Program Studi

Magister Kebijakan dan

Pengembangan Pendidikan

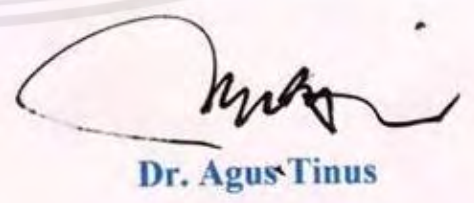




\section{TESIS}

\section{MAULIDIN ARDIYANSYAH W.P 201710240211014}

Telah dipertahankan di depan Dewan Penguji

Pada hari/tanggal, Kamis 28 Maret 2019

Dan dinyatakan memenuhi syarat sebagai kelengkapan Memperoleh gelar/Magister/ Profesi di Program Pascasarjana

- Universitas Muhammadiyah Malang

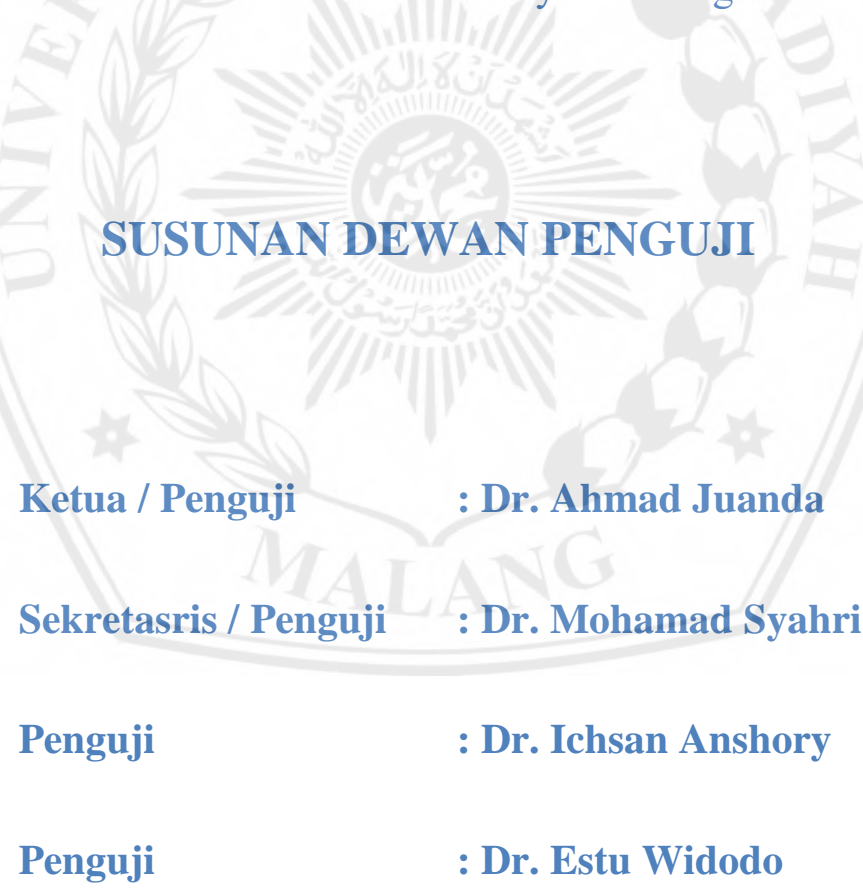




\section{SURAT PERNYATAAN}

Yang bertanda tangan di bawah ini, saya:

Nama

: MAULIDIN ARDIYANSYAH W.P

NIM

: 201710240211014

Program Studi

: Magister Kebijakan dan Pengembangan Pendidikan

Dengan ini Menyatakan dengan Sebenar-benarnya bahwa:

1. Tesis dengan judul : STUDI KEBIJAKAN PENGIKUTSERTAAN ORANGTUA TERHADAP PENINGKATAN MUTU PENDIDIKAN DI SDN SONGGOKERTO 3 KOTA BATU Adalah karya saya dan dalam naskas Tesís ini tidak terdapat karya ilmiah yang pernah diajukan oleh orang lain untuk memperoleh gelar akadek di suatu Perguruan Tinggi dan tidak terdapat karya atau pendapat yang pernah ditulis atau diterbitkan oleh orang lain, baik sebgaian maupun keseluruhan, kecuali yang secara tertulis dikutip dalam naskah ini dan disebutkan dalam sumber kutipan dalam daftar pustaka.

2. Apabila ternyata dalam naskah Tesis ini dapat dibuktikan terdapat unsurunsur PLAGIASI, saya bersedia Tesis ini DIGUGURKAN dan GELAR AKADEMIK YANG TELAH SAYA PEROLEH DIBATALKAN, serta diproses sesuai dengan ketentuan hukum yang berlaku.

3. Tesis ini dapat dijadikan pustaka yang merupakan HAK BEBAS ROYALTY NON EKSKLUSIF.

Demikian pernyataan ni saya buat dengan sebenarnya untuk dipergunakan sebgaiaman mestinya.

Malang, 21 Maret 2019

Yang menyatakan,

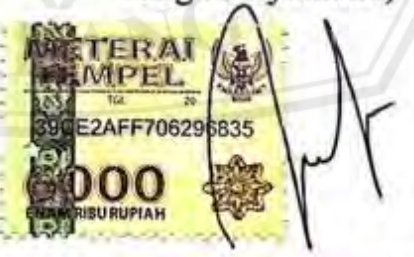

MAULIDIN ARDIYANSYAH W.P 


\section{KATA PENGANTAR}

Puji syukur kami ucapkan kepada Allah SWT yang telah melimpahkan rahmat serta karunia-Nya sehingga Tesis yang berjudul "Studi Kebijakan Pengikutsertaan Orangtua Terhadap Peningkatan Mutu Pendidikan Di SDN Songgokerto 3 Kota Batu" ini dapat terselesaikan, meskipun bersifat sangat sederhana.

Penyelesaian Tesis ini tidak terlepas dari petunjuk arahan, bimbingan serta dukungan yang diberikan oleh dosen pembimbing serta bantuan dari berbagai pihak. Oleh karena itu, pada kesempatan ini dengan segala kerendahan hati dan rasa hormat, disampaikan terimakasih kepada :

1. Akhsanul In'am, Ph.D selaku Direktur Program Pascasarjana Universitas Muhammadiyah Malang yang memberikan perijinan untuk penulis melakukan penelitian.

2. Dr. Agus Tinus selaku Ketua Program Studi Magister Kebijakan dan Pengembangan Pendidikan Universitas Muhammadiyah Malang yang memberikan kesempatan penulis untuk menulis Tesis.

3. Dr. Ahmad Juanda, selaku pembimbing I yang telah mengorbankan waktu, tenaga, pikiran atas kesediaan dan ketelatenannya dalam membimbing dan memberi pengarahan kepada penulis sehingga Tesis ini dapat terselesaikan dengan baik.

4. Dr. Mohamad Syahri selaku pembimbing II yang telah mengorbankan waktu, tenaga, pikiran atas kesediaan dan ketelatenannya dalam membimbing dan memberi pengarahan kepada penulis sehingga Tesis ini dapat terselesaikan dengan baik.

5. Seluruh dosen Program Studi Magister Kebijakan dan Pengembangan Pendidikan yang telah memberikan ilmu pengetahuan pada penulis selama menjadi mahasiswa.

Penulis menyadari bahwa penulisan Tesis ini masih sangat jauh dari kata sempurna, sehingga masukan dan kritik akan selalu penulis harapkan untuk memperbaiki Tesis ini.

Akhir kata penulis memohon maaf yang sebesar-besarnya jika dalam proses pembuatan Tesis ini penulis melakukan kesalahan baik yang disengaja maupun tidak sengaja.

Malang,

Penulis 


\begin{abstract}
ABSTRAK
Panggayuh, Maulidin Ardiyansyah W.2019.Studi Kebijakan Pengikutsertaan Orangtua Terhadap Peningkatan Mutu Pendidikan di SDN Songgokerto 3 Kota Batu. Tesis, Magister Kebijakan dan Pengembangan Pendidikan Universitas Muhammadiyah Malang. Pembimbing: 1) Dr. Ahmad Juanda.; 2) Dr. Mohamad Syahri
\end{abstract}

Mutu merupakan suatu istilah yang digunakan untuk menggambarkan kualitas barang atau jasa. Istilah mutu jika diposisikan dalam dunia pendidikan maka mutu pendidikan dapat diartikan sebagai apakah sekolah ataupun siswa telah sesuai dengan standar yang sudah ditetapkan oleh pemerintah yaitu standar nasional pendidikan. Demi tercapainya pendidikan yang bermutu, sekolah tidak bisa berjalan sendiri, sekolah memerlukan dukungan dari orang tua siswa baik dukungan moril atau materil. Tujuan penelitian ini adalah 1) untuk mengetahui bagaimana bentuk partisipiasi orangtua di SDN Songgokerto 3 Kota Batu, 2) untuk mengetahui bagaimana strategi sekolah dalam menumbuh kembangkan partisipasi orang tua di SDN Songgokerto 3 Kota batu. Penelitian ini merupakan penelitian deskriptif kualitatif yang bertempat di SDN Songgokerto 3 Kota Batu dengan teknik pengumpulan data menggunakan teknik wawancara, observasi, dan dokumentasi. Hasil dari penelitian ditemukan bahwa kebijakan yang telah di tetapkan oleh kepala sekolah adalah dengan mengikut sertakan orangtua dalam setiap program kegiatan yang ada di sekolah, strategi yang digunakan adalah dengan menjalin komunikasi yang baik salah satunya dengan ikut dalam setiap kegiatan yang ada di masyarakat lingkungan sekolah salah satunya adalah pengajian. Bentuk partisipasi dari orangtua di SDN Songgoketo 3 Kota Batu berupa pemikiran, keterampilan, tenaga, uang, dan benda.

Kata Kunci: Mutu Pendidikan, Partisipasi Orangtua 


\begin{abstract}
Panggayuh, Maulidin Ardiyansyah W.2019. Study of the Policy of Parent's Participation in Education Quality Improvement in Songgokerto Elementary School 3, Batu City. Tesis, Master of Education Policy and Development Muhammadiyah Malang University. Advistor: 1) Dr. Ahmad Juanda; 2) Dr. Mohamad Syahri

Quality is a term used to describe the quality of goods or services. The term quality if positioned in the world of education, the quality of education can be interpreted as whether the school or students are in accordance with the standards set by the government, namely the national standard of education. For the sake of achieving quality education, schools cannot run on their own, schools need support from parents of students both moral or material support. The purpose of this study was 1) to find out how the form of parental participation in SDN Songgokerto 3 Kota Batu, 2) to find out how the school's strategy in developing parental participation in SDN Songgokerto 3 Batu City. This research is a qualitative descriptive study that took place in SDN Songgokerto 3 Batu City with data collection techniques using interview, observation, and documentation techniques. The results of the study found that the policy set by the principal was to include parents in every activity program in the school, the strategy used was to establish good communication, one of which was by participating in any activities in the school community. one is pray. The form of participation from parents in Songgoketo Elementary School 3 Batu City in the form of thoughts, skills, energy, money, and objects.
\end{abstract}

Key Word: Quality of Education, Parent Participation 
Halaman Judul ................................................................................... i

Halaman Persetujuan ..................................................................................... ii

Surat Pernyataan ................................................................................................................ iv

Kata Pengantar .................................................................................. v

Abstrak............................................................................................................................ vi

Abstract..................................................................................................... vii

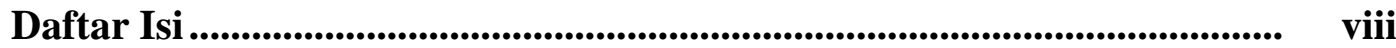

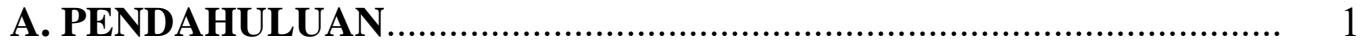

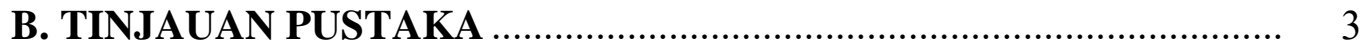

1. Pengertian Mutu Pendidikan ......................................................... 3

2. Indikator Sekokah Bermutu....................................................... 4

3. Partisipasi Orangtua ................................................................... 5

4. Peran Orangtua di Dunia Pendidikan ............................................ 5

5. Hubungan Orangtua dan Sekolah .................................................. 6

6. Bentuk-Bentuk Partisipasi ................................................................. 7

7. Teori Kebijakan Model Merilee S. Grindle...................................... 8

C. METODE PENELITIAN .............................................................. 9

1. Pendekatan dan Jenis Penelitian ....................................................... 9

2. Tempat Penelitian ......................................................................... 9

3. Instrument Penelitian .................................................................... 9

4. Sumber Data ......................................................................... 9

5. Teknik Pengumpulan Data _......................................................... 10

6. Teknik Analisis Data ................................................................ 10

7. Keabsahan Data ............................................................................. 12

8. Kerangka Konseptual ..................................................................... 12

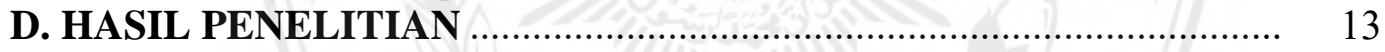

1. Peran Kepala Sekolah dalam Keterlibatan Orangtua di Sekolah ...... 13

2. Peran Serta Orangtua dalam Peningkatan Mutu Sekolah................. 16

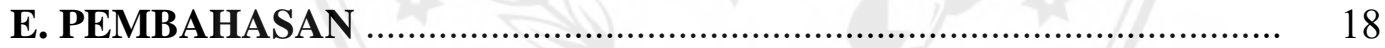

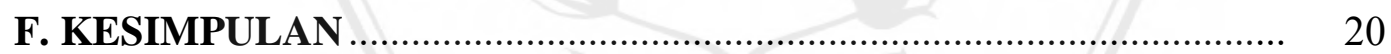

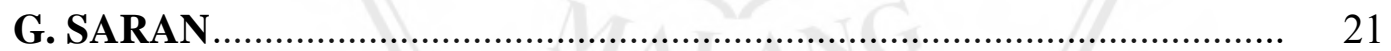

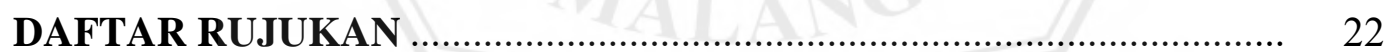




\section{A. Pendahuluan}

Sekolah dalam peranannya mempersiapkan sumberdaya manusia yang berkualitas perlu untuk mempersiapkan mutu yang baik dalam pelaksanaan pendidikan. Mutu pendidikan dapat menjadi indikator tingkat kesejahteraan masyarakat dari suatu Negara. Melalui pendidikan yang bermutu suatu Negara dapat menghasilkan sumber daya manusia yang dapat mengelola sumberdaya yang lain secara efektif dan efisien. Mutu sendiri merupakan suatu istilah yang digunakan untuk menggambarkan tingkat kesesuaian suatu hal terhadap persyaratan yang sudah ditetapkan atau keunggulan yang dimiliki (Basri, 2011). Pendapat serupa juga disampaiakan oleh Uamedi (2004) yang menyatakan bahwa mutu merupakan suatu keadaan dimana produk atupun jasa sudah memenuhi persyaratan atau kriteria yang sudah di tetapkan. Istilah mutu dan sekolah jika digabungkan maka dapat dimaknai menjadi upaya yang dilakukan oleh sekolah dalam memberikan layanan yang terbaik untuk memenuhi keinginan dari peserta didik (Kurniasih \& Radiana, 2013).

Faktor-faktor utama dalam peningkatan mutu pendidikan antara lain adalah bentuk kepemimpinan dari kepala sekolah, guru, siswa, kurikulum, dan jaringan kerjasama yang dilakukan oleh sekolah (Saifulloh, Muhibbin, \& Hermanto, 2012). Pemerintah juga telah menyadari pentingnya pendidikan yang bermutu untuk mencetak sumberdaya manusia yang berkualitas. Upaya yang dilakukan pemerintah untuk meningkatkan mutu pendidikan di Indonesia seperti melakukan perubahan-perubahan untuk penyempurnaan kurikulum (Kurniasih \& Radiana, 2013). Selain dengan melakukan perubahan kurikulum pemerintah juga menetapkan Undang-Undang Nomor 20 Tahun 2003 tentang Sistem Pendidikan Nasional yang digunakan sebagai acuan dalam penyelenggaraan pendidikan (Basri, 2011), sedangkan untuk menjamin terselenggaranya pendidikan yang bermutu pemerintah juga menetapkan Peraturan Pemerintah Nomor 32 Tahun 2013 Tentang Standar Nasional Pendidikan. Pendidikan merupakan bidang yang tidak hanya menjadi tanggung jawab pemerintah namun masyarakat yang dalam hal ini berari orangtua juga ikut berperan dalam terselenggaranya pendidikan yang bermutu.

Peran serta orang tua dalam pendidikan memiliki posisi yang sangat penting mengingat demi tercapinya pendidikan yang bermutu perlu pembiayaan dan dukungan dari bebagai pihak yang cukup tinggi untuk melengkapi komponen-komponen yang harus dipenuhi, selain itu motivasi dari orang tua juga diperlukan untuk meningkatkan 
berbagai aspek intelegensi yang dimiliki oleh anak baik aspek kognitif, afektif, maupun psikomotorik demi terpenuhiya pendidikan yang bermutu(Yanuartri, Jufri, \& Syuaib, 2016).

Kepedulian akan pentingnya partisipasi masyarakat dalam hal ini orang tua di dunia pendidikan saat ini masih tergolong rendah (Falah, 2012; Rohmah, 2016), rendahnya partisipasi orangtua disebabkan karena beberapa faktor seperti faktor budaya, tingkat pendidikan orangtua, dan sikap orangtua yang cenderung sepenuhnya mempercayakan pendidikan anaknya kepada sekolah(Yanuartri, 2016).

Sekolah Dasar Negeri Songgokerto 3 Kota Batu merupakan sekolah yang terletak di jalan Arum Dalu Nomor 65 A Kecamatan Batu Kota Batu. Berdasarkan hasil observasi yang dilakukan oleh peneliti pada beberapa narasumber, SDN Songgokerto 3 semula mengalami penurunan jumlah siswa pada setiap tahunnya dan rasa percaya dari masyarakat kepada tenaga pendidik di SDN Songgokerto 3 cenderung kurang. Setelah adanya pergantian kepala sekolah kendala yang dihadapi oleh sekolah berangsur-angsur membaik mulai dari jumlah siswa pada setiap tahunnya meningkat dan rasa percaya masyarakat yang semula kurang dapat meningkat yang berdampak pada terbentuknya komunikasi yang baik dan rasa memiliki masyarakat terhadap sekolah tinggi. Terjalinnya komunikasi yang baik dan rasa memiliki masyarakat pada sekolah prestasi yang diperoleh oleh sekolah yang tidak terlepas dari turut andilnya masyarakat salah satunya mendapatkan penghargaan sekolah adiwiyata pada tingkat Jawa Timur.

Penelitian yang dilakukan oleh Anggraeni, Yoto, \& Basuki (2015) yang berjudul "Studi Tentang Peran Serta Orang Tua dan Dunia Usaha/Industri Dalam Peningkatan Mutu Pendidikan Di SMK Negeri 1 Singosari" menunjukkan bentuk peran serta orang tua siswa dalam meningkatkan mutu pendidikan yaitu 1) Peran serta orang tua dalam Sumbangan penyelenggaraan pendidikan, 2) peran serta orang tua dalam pendanaan fasilitas pendidikan, dan 3) peran orang tua dalam kegiatan belajar mengajar. Penelitian yang lain yang dilakukan oleh Yanuarti, Jufri, \& Syuaib (2016) yang berjudul “Kontribusi Partisipasi Orang Tua dan Kompetensi Sosial Guru Terhadap Mutu Pendidikan Di Sekolah Dasar Gugus 01 Kecamatan Ampenan Kota Mataram" didapatkan hasil penelitian partisipasi orang tua memiliki kontribusi positif dalam meningkatkan mutu pendidikan di Sekolah Dasar Gugus 01 Kecamatan Ampenan. 
Berdasarkan latar belakang diatas penulis tertarik untuk melakukan penelitian dengan judul "Studi Kebijakan Pengikutsertaan Orangtua Terhadap Peningkatan Mutu Pendidikan di SDN Songgokerto 3 Kota Batu" dengan rumusan masalah 1) Bagaimana bentuk partisipasi orang tua di Sekolah Dasar Negeri Songgokerto 3 Kota Batu? 2) Bagaimana strategi sekolah dalam menumbuh kembangkan partisipasi orang tua di Sekolah Dasar Negeri Songgokerto 3 Kota Batu?

\section{B. TINJAUAN PUSTAKA}

\section{Pengertian Mutu Pendidikan}

Istilah mutu banyak sekali didefinisakn oleh para ahli. Rumusan tentang mutu bersifat dinamis dan dapat diartikan dari berbagai sudut pandang salah satunya dirumuskan oleh Uamedi (2004) yang menyatakan bahwa mutu merupakan suatu keadaan dimana produk atupun jasa sudah memenuhi persyaratan atau kriteria yang sudah di tetapkan. Produk ataupun jasa yang dihasilkan tidak harus yang terbaik, namun produk ataupun jasa yang dihasilkan telah memenuhi standar yang ditetapkan.

Pengertian mengenai mutu menurut Sani, Pramuniati, \& Mucktiany (2015) dibagi menjadi dua yaitu mutlak dan relative. Pengertian mutu yang bersifat mutlak adalah sifat yang terlihat cantik, baik yang telah sesuai dan tidak dapat dikompromikan kembali, sedangkan pengertian yang bersifat relatif memandang mutu berasal dari layanan yang sudah di berikan dari suatu produk. Dapat ditarik kesimpulan bahwa mutu adalah tingkatan tentang baik atau buruknya suatu barang atau jasa.

Pengertian tentang mutu jika dilihat dari sudut pandang pendidikan dapat diartikan bahwa sekolah ataupun siswa telah memiliki standar atau keahlian yang sudah di tetapkan oleh pemerintah berdasarkan standar nasional pendidikan. Selain itu menurut Edward (2011) mutu pendidikan adalah tingkat kesesuaian antara kebutuhan pihak yang berkepentingan dalam hal ini berarti stakeholder dengan layanan yang telah diberikan pengelola pendidikan.

Stakeholder dapat dibagi menjadi dua yaitu stakeholder eksternal dan internal. Stakeholder eksternal adalah pemerintah, orangtua, masyarakat umum, dan masyarakat khusus (dunia pekerjaan). Sedangkan stakeholder internal meliputi guru, kepala sekolah, dan tenaga pendidikan. 
Mutu pendidikan dalam usaha untuk menuhi kebutuhan dari stakeholder perlu memperhatikan bahwa manajemen mutu sekolah merupakan suatu perangkat atau prosedur atau hakikat atau proses untuk memperbaiki mutu sekolah, Oleh karena itu manajemen mutu sekolah dapat digunakan untuk mengelola seluruh sumber daya yang ada di sekolah dengan mengarahkan semua pihak untuk melaksanakan tugasnya sesuai dengan standar yang telah ditetapkan sehingga dapat menghasilkan lulusan yang berkualitas.

\section{Indikator Sekolah Bermutu}

Untuk mengukur pendidikan yang berkualitas tentunya diperlukan kriteria/ indikator. Sallis (2005) mengungkapkan ada banyak indikator mutu yang baik di lembaga pendidikan. Antara lain:

1) Nilai moral yang tinggi

2) Hasil ujian masuk pada kategori baik

3)Mendapatkan dukungan dari orang tua dan masyarakat yang berada di lingkungan

4) Memiliki sumber daya yang melimpah

5) Mengimplementasikan teknologi terbaru

6) Pemimpin yang kuat dan memiliki tujuan yang jelas

7) Kepedulian pada siswa

8) kurikulum yang seimbang dan relevan.

\section{Partisipasi Orangtua}

Partisipasi menurut Normina (2016) merupakan suatu bentuk pemberian atau sumbangan yang dilakukan oleh masyarakat. Sedangkan menurut Hancock (2015) partisipasi merupakan suatu bentuk keterlibatan dari seseorang yang dilakukan secara sadar dalam berinteraksi dengan lingkungannya pada suatu keadaan tertentu.

Partisipasi masyarakat dalam dunia pendidikan juga telah diatur dalam Peraturan Pemerintah No 17 Tahun 2010 Tentang Pengelolaan dan Penyelenggaraan Pendidikan yang berbunyi "Peran serta masyarakat dalam pendidikan berfungsi memperbaiki akses, mutu, daya saing, relevansi, tatakelola, akuntabilitas pengelolaan dan penyelenggaraan pendidikan". Selain itu dalam Peraturan Pemerintah no 39 tahun 1992 tentang Peran Serta 
Masyarakat dalam Pendidikan Nasioanal juga menyebutkan "Partisipasi atau peran serta masyarakat berfungsi untuk ikut memelihara, menumbuhkan, dan meningkatkan sera mengembangkan pendidikan nasional"

\section{Peran Orangtua di Dunia Pendidikan}

Orangtua merupakan sosok yang paling utama dalam tercukupinya pendidikan anak. Anak meskipun telah dititipkan di sekolah, orang tua tetap memiliki peran yang penting terhadap prestasi yang diraih oleh anak. Menurut Umar (2015) hal yang perlu disiapkan oleh orangtua untuk meningkatkan prestasi anak adalah:

1) Memfasilitasi anak untuk menemukan minat, bakat, dan keahlian lain yang dimiliki anak.

2) Menyediakan informasi yang relevan dan dapat digunakan untuk mengembangkan bakat dan minat anak.

3) Menyediakan fasilitas atau sarana untuk membantu anak dalam proses belajar.

Raraswati (2016) juga menyampaikan bahwa orangtua memiliki peran sebagai berikut:

1) Menciptakan suasana belajar yang menyenangkan

2) Menjalin komunikasi yang baik dengan anak.

3) Selalu memberikan motivasi untuk meningkatkan rasa percaya diri yang dimiliki oleh anak

4) Menjalin komunikasi yang aktif dengan sekolah dan menciptakan lingkungan yang kondusif untuk proses belajar dan mengajar

5) Berpartisi aktif dalam setiap kegiatan keluarga yang dilaksanakan di sekolah

\section{Hubungan Orangtua dan Sekolah}

Mengingat salah satu kunci sukses manajemen dalam menggalang partisipasi orang tua adalah menjalin hubungan yang harmonis, maka sekolah perlu memprogramkan beberapa hal (Mulyasa, 2000) sebagai berikut.

1.Melibatkan orang tua secara profesional dalam mengembangkan perencanaan, pelaksanaan dan program sekolah.

2.Menjalin komunikasi secara intensif. Secara proaktif sekolah menghubungi orang tua siswa 
3.Mengadakan pembagian tugas dan tanggung jawab antara sekolah dengan orang tua dalam pembinaan pribadi siswa.

4.Melibatkan orang tua dalam berbagai program dan kegiatan sekolah yang bersifat sosial kemasyarakatan,

5.Melibatkan orang tua dalam mengambil berbagai keputusan, agar mereka merasa bertanggung jawab untuk melaksanakannya.

6.Mendorong guru untuk mendayagunakan orang tua sebagai sumber belajar dan menunjang keberhasilan belajar peserta didik

Sejalan dengan hal tersebut menurut Saraswati (2016) sebagai realisasi dari bentuk tanggung jawab dalam penyelenggaraan pendidikan, diperlukan adanya kerjasama yang harmonis antara keluarga, sekolah, dan masyarakat sebagai bentuk kemitraan, pentingnya kemitraan sekolah dengan keluarga yaitu:

1. Keluarga adalah pendidik yang pertama dan utama, tetapi dalam praktiknya masih banyak keluarga yang menyerahkan sepenuhnya tanggung jawab pendidikan anak pada sekolah

2. Peran sekolah adalah membantu keluarga agar pelaksanaan pendidikan lebih sistimatis, efektif, dan hasilnya tersertifikasi

3. Tidak semua kebutuhan pendidikan anak dapat dipenuhi oleh satuan pendidikan maupun keluarga

4. Kerjasama keluarga dengan satuan pendidikan mutlak diperlukan

5. Satuan pendidikan wajib mendorong kemitraan dan pelibatan keluarga dalam memajukan pendidikan anak mereka

\section{Bentuk-Bentuk Partisipasi}

Bentuk-bentuk partisipasi tersebut menurut (Choresyo, Nulhaqim, \& Wibowo, 2017), membagi 5 bentuk partisipasi, yaitu (1) Partisipasi buah pikiran, (2) Partisipasi keterampilan, (3) Partisipasi tenaga, (4) Partisipasi uang, dan (5) Partisipasi harta benda. Pendapat yang lain mengatakan, ada enam jenis partisipasi yaitu:

1) Partisipasi pemikiran. Partisipasi masyarakat pada bentuk pemikiran merupakan jenis partisipasi menyampaikan pendapat atau masukan yang sifatnya untuk membangun, memberikan usulan, serta memberikan usulan maupun kritik. 
2) Partisipasi tenaga. Partisipasi tenaga merupakan partisipasi dilakukan oleh seseorang dengan menyumbangkan tenaganya yang berguna untuk menunjang keberhasilan dari suatu kegiatan. Seseorang yang berpartisipasi dalam bentuk tenaga salah satu alasannya adalah karena memiliki waktu yang cukup untuk menyumbangkan tenaganya dalam pelaksanaan program.

3) Partisipasi dalam bentuk keahlian. Partisipasi keahlian merupakan partisipasi yang dilakukan orang tertentu yang memiliki keahlian dan dibutuhkan dalam pelaksanaan suatu program kegiatan. Berjalannya suatu program dengan adanya seseorang yang berpartisipasi dalam bentuk keahlian selain menyumbangkan keahliannya juga melatih dalam memanfaatkan keahlian yang sudah dimilikinya sehingga keahlian yang sudah dimiliki dapat terberdayakan.

4) Partisipasi dalam bentuk barang. Bentuk partisipasi berupa barang dapat digambarkan masyarakat memberikan atau menyumbangkan barang yang sudah dimiliki untuk tercapainya suatu program kegiatan. Selain itu bentuk partisipasi berupa barang dapat disebabkan karena tidak bisa memberikan partisipasi pada bentuk yang lain, sehingga memiliki barang tertentu yang dapat disumbangkan dalam suatu program kegiatan.

5) Partisipasi dalam bentuk uang. Seseorang berpartisipasi dalam bentuk uang dapat disebabkan oleh dua faktor, yaitu (1) faktor kesibukan yaitu karena disibukkan oleh aktivitas sehari-hari sehingga tidak mempunyai waktu luang untuk berpartisipas dalam bentuk yang lain, dan (2) faktor kemampuan ekonomi yaitu partisipasi yang dilakukan oleh seseorang yang memiliki kemampuan untuk menyumbang dalam bentuk uang.

\section{Teori Kebijakan Model Merilee S. Grindle}

Model implementasi kebijakan menurut Grindle (1980) dikenal dengan Implementation as A Political and Administrative Process. Tingkat keberhasilan suatu kebijakan menurut Merilee S. Grindle dapat diukur dari proses pencapaian yang sudah dilaksanakan. Tingkat keberhasilan atau tidaknya suatu kebijkan dapat dilihat dari prosesnya dan ketercapaian tujuan pendidikan. 
Implementability menurut Grindle juga turut andil dalam keberhasilan implementasi kebijakan yang terdiri dari content of policy dan contentext of policy. Content of policy menurut Grindle terdiri dari beberapa bagian yaitu: 1)Kepentingan yang mempengaruhi, 2) Tipe manfaat, 3) Derajat, perubahan yang ingin dicapai, 4) Letak pengambilan keputusan, 5) Pelaksana program, 6) Sumber daya yang digunakan

Sementara itu pada contentext of policy terdiri dari: 1) Kekuasaan, kepentingan, strategi dari aktor yang terlibat, 2) Karakteristik lembaga, 3) Tingkat kepatuhan dan adanya respon dari pelaksana.

\section{METODE PENELITIAN}

\section{Pendekatan dan Jenis Penelitian}

Penelitian tentang "Studi Kebijakan Pengikutsertaan Orangtua Terhadap Peningkatan Mutu Pendidikan di SDN Songgokerto 3 Kota Batu" ini menggunakan pendekatan kualitatif. Penelitian ini merupakan penelitian yang bersifat kualitatif. Penelitian kualitatif adalah penelitian yang bertujuan untuk memahami fenomena yang dialami oleh subjek penelitian, seperti motivasi, perilaku, persepsi, tindakan, dll, dengan cara mendeskripsikan dalam bentuk kata-kata(Moleong, 2013).

Jenis penelitian yang digunakan dalam penelitian ini adalah penelitian kualitatif deskripstif, yaitu bertujuan untuk menggambarkan dan atau mendeskripsikan karakteristik dari fenomena (Ulfatin, 2013).

\section{Tempat Penelitian}

Lokasi penelitian adalah suatu tempat dimana penelitian tersebut akan dilakukan. Lokasi penelitian dalam penelitian ini adalah di Sekolah Dasar Negeri 3 Kecamatan Songgokerto Kota Batu.

\section{Instrumen Penelitian}

Dalam metode ini peneliti berusaha menafsirkan makna suatu peristiwa interaksi tingkah laku manusia dalam situasi tertentu menurut perspektif peneliti. Responden yang ada dalam metode kualitatif terus berkembang secara bertujuan hingga data yang dikumpulkan dirasa sudah cukup dan memuakan. Alat pengumpul data atau instrument penelitian metode kualitatif 
adalah si peneliti sendiri sehingga peneliti merupakan key instrument (Usman, 2003).

\section{Sumber Data}

Sumber data adalah subjek darimana data tersebut didapat, yakni semua orang yang sudah dijadikan informan oleh peneliti didalam sebuah penelitiannya (Arikunto, 2006). Sumber data yang digunakan dalam penelitian ini adalah sumber data hasil wawancara (primer) dan sumber data hasil studi pustaka (sekunder).

\section{Teknik Pengumpulan Data}

Teknik pengumpulan data adalah langkah yang utama didalam penelitian, karena tujuan utama dalam penelitian adalah memperoleh data. Peneliti adalah instrument utama didalam pengumpulan data, yang menggunakan metode observasi dan wawancara. Pengertian instrument atau alat penelitian disini adalah tepat, karena ia segalanya dari keseluruhan proses penelitian(Moleong, 2013). Teknik pengumpulan data dalam penelitian ini menggunakan metode wawancara, observasi, dan dokumentasi.

\section{Teknik Analisis Data}

Analisis data dalam penelitian kualitatif dilakukan pada saat pengumpulan data berlangsung, setelah selesai pengumpulan data dalam periode tertentu (Sugiyono, 2013). Aktivitas dalam analisis data kualitatif dilakukan secara interaktif dan berlangsung secara terus menerus sampai tuntas, sehingga datanya jenuh (Miles \& A.M, 1984). Kejenuhan data dalam penelitian kualitatif ditandai dengan tidak ditemukannya kembali informasi baru yang didapat.

Analisis data dalam penelitian kualitatif merupakan proses menyusun dan mencari yang sifatnya sistematis. Hal ini dapat dilakukan dengan pengorganisasian data, menjabarkan ke dalam unit-unit, menyusun ke dalam pola, melakukan sintesa, memilih mana yang penting dan membuat kesimpulan yang bisa di berikan kepada orang lain.

Sehingga bisa dikatakan analisis data adalah suatu proses pencarian dan penyusunan data secara sistematis yang didapat dari hasil observasi, wawancara, catatan lapangan, dokumentasi dan dilakukan dengan 
pengorganisasia, penjabaran, melakukan sintesa, penyusunan pola, dan pemilihan mana yang penting dan pembuatan kesimpulan.

Kegiatan dalam analisis data terdiri dari mereduksi data (data reduction), menyajikan data (data display) serta penarikan kesimpulan / verifikasi (conclusion drawing / verifying).

\section{1) Reduksi Data (Data Reduction)}

Reduksi data adalah proses analisis data yang dilakukan dengan memilih hal-hal yang pokok, memfokuskan pada hal-hal yang penting, dicari tema dan polanya. Data yang didapatkan dari lapangan ditulis/diketik dalam bentuk uraian atau laporan yang terperinci.

Proses mereduksi data dapat dilakukan dengan mendikusikan pada teman atau orang lain yang dipandang ahli. Melalui diskusi diharapkan wawasan peneliti lebih berkembang, data hasil reduksi lebih bermakna dalam menjawab pertanyaan penelitian.

\section{2) Penyajian Data (Data Display)}

Penyajian data dilakukan dalam bentukuraian singkat, bagan, hubungan antar kategori, flowchart, dan sejenisnya. Penyajian data penelitian kualitatif paling sering menggunakan teks yang bersifat naratif.

\section{3) Penarikan Kesimpulan/verifikasi (Conclusion Drawing/verifying)}

Dari data yang didapatkan, selanjutnya dikategorikan, dicari tema dan polanya kemudian ditarik kesimpulan. Kesimpulan yang sudah dikemukakan di awal sifatnya masih sementara, dan akan berubah jika tidak ditemukan bukti-bukti yang mendukung pada tahap pengumpulan data yang akan dilakuakn pada tahapan selanjutnya. 


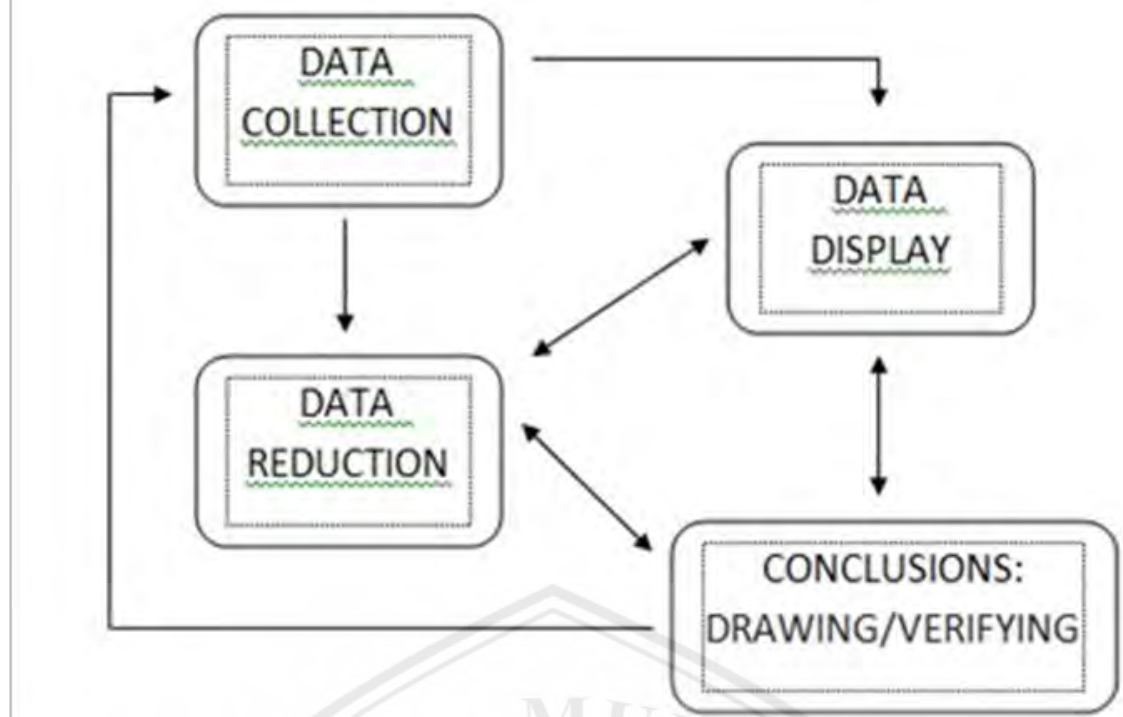

Sumber Data: Model Interaktif Miles dan Huberman, (1984:20)

Analisis data dalam penelitian kualitatif ini dilakukan sejak sebelum datang di lapangan, selama di lapangan, dan setelah di lapangan. Sugiyono (2013) mengungkapkan bahwa analisis telah dimulai sejak perumusan masalah, sebelum datang ke lapangan, dan ketika berada di lapangan sampai penulisan hasil penelitian.

\section{Keabsahan Data}

Mendapatkan pertanggung jawaban dari kebasahan data yang di dapat, maka peneliti menggunakan teknik triangulasi Wiersma (1986) yang menyatakan, triangulasi dalam pengujian kredibilitas ini diartikan sebagai pengecekan data dari berbagai sumber dengan berbagai cara dan berbagai waktu. Pada penelitian ini peneliti menggunakan teknik triangulasi sumber dan triangulasi metode. 


\section{Kerangka Konseptual}

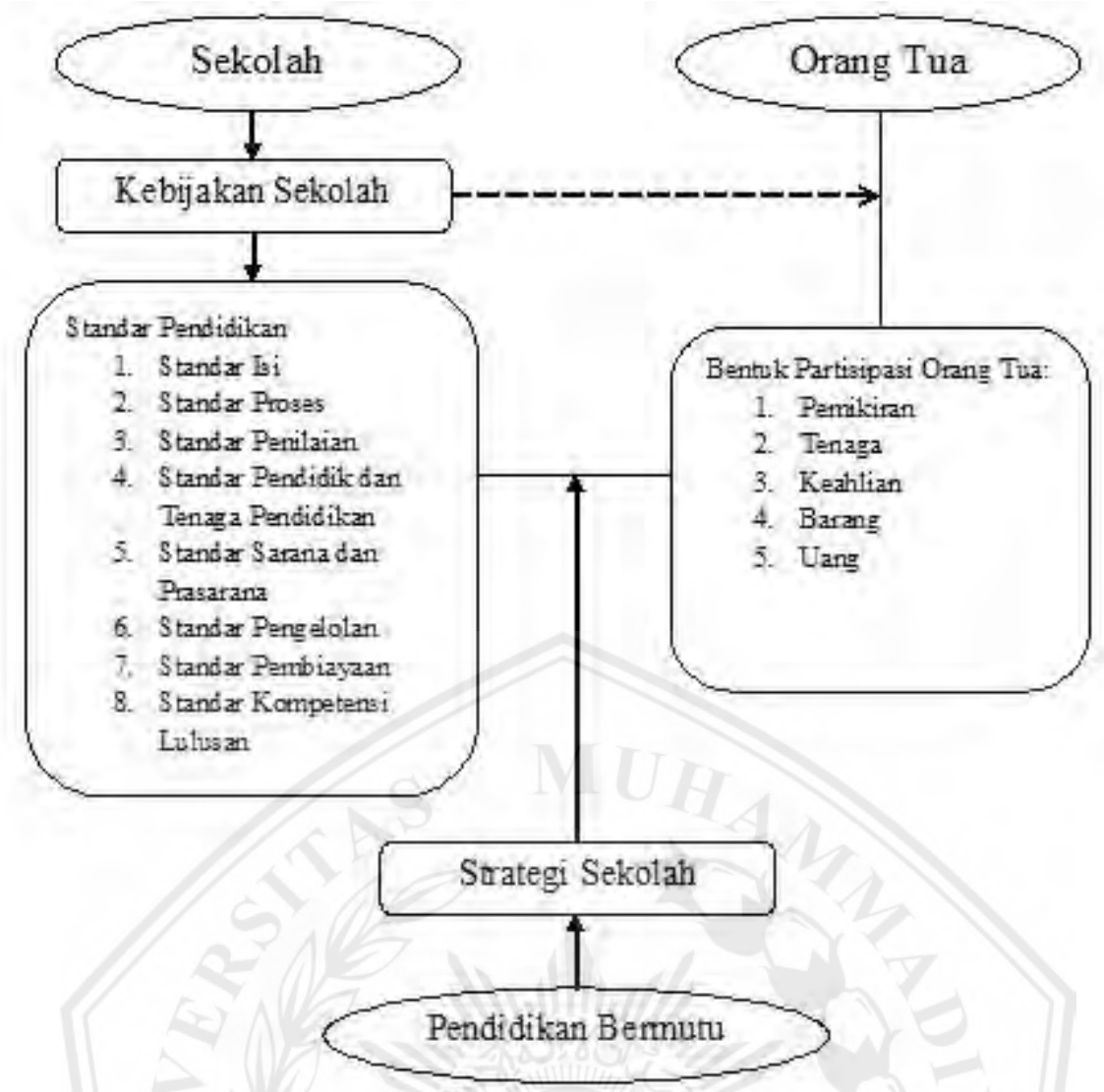

Sumber data: Diambil dari berbagai sumber dan diolah oleh peneliti

\section{HASIL PENELITIAN}

\section{Peran Kepala Sekolah dalam Keterlibatan Orang Tua Di Sekolah}

Pemimpin merupakan seseorang yang memiliki keahlian tertentu untuk mempengaruhi kelompok yang sedang di pimpinnya untuk mencapai suatu tujuan tertentu (Herispon, 2010). Pemimpin di sekolah adalah kepala sekolah, dimana kepala sekolah sebagai pemimimpin harus dapat memberikan pengaruh yang positif terhadap lingkungannya, selain itu baik atau tidaknya suatu sekolah salah satu faktor yang mempengaruhi adalah gaya kepemimpinan kepala sekolah.

Kepala sekolah sebagai seorang yang memiliki wewenang di sekolah berada pada posisi yang sangat penting dari kemajuan sekolah yang dipimpinnya. Sebaik dan selengkap apapun sumberdaya yang dimiliki oleh sekolah akan tidak berarti apa-apa jika tidak diberdayakan dan dikelolah dengan baik oleh kepala sekolah, oleh karena itu yang berperan dalam mengkoordinasikan usaha untuk meningkatkan pendidikan yang bermutu di sekolah adalah kepala sekolah. 
Upaya yang dilakukan oleh kepala sekolah di SDN Songgokerto 3 Kota Batu untuk tercapainya pendidikan yang bermutu adalah dengan melibatkan orang tua dalam setiap program yang ada di sekolah seperti program pembelajaran, penyediaan sarana dan prasarana di sekolah, dan ekstrakulikuler. hal tersebut sesuai dengan penuturan kepala sekolah.

"Ya setiap program sekolah selalu melibatkan orangtua seluruhnya, iya baik program pembelajaran, kemudian untuk kelengkapan sarpras, kegiatan ektrakulikuler, semuanya melibatkan orangtua" (KS/1-12-18).

Program-program yang ada disekolah dan dilakukan bersama-sama dengan orang tua maupun masyarakat adalah setiap tiga bulan sekali dilakukan kerja bakti di sekolah, pembenahan-penahan sarana dan prasarana seperti pengecatan ulang dinding, kursi dan meja belajar, rapat komite yang dilakukan setiap tiga bulan sekali, pengajian setiap jumat legi, manasik haji yang dilaksanakan setiap tahun bersama dengan TK dan PAUD yang berada di sekitar sekolah. hal tersebut sesuai dengan penuturan kepala sekolah.

"Program-program yang melibatkan masyarakat ya seperti pembenahan, kerja bakti, ya untuk menciptakan suasana sekolah yang bersih terutama adiwiyata itu juga ada hubungannya dengan walimurid, tiap tiga bulan sekali ada kerja bakti kemudian ada juga rapat komite juga tiga bulan sekali, kemudian kegiatan-kegiatan yang sifatnya apa ya memperingati hari besar agama yang sekiranya tidak bisa di cover oleh sekolah ya kerjasama dengan orang tua. Seperti latihan manasik haji setiap tahunkan? tiap tahun itu melibatkan komite, paguyupan, orang tua, kemudian TK Kusuma Pertiwi, PAUD Arumdalu, itu semua kita libatkan disini. jadi itu memang sudah ada programnya" (KS/1-12-18).

Penuturan yang serupa juga disampaikan oleh ketua komite yang menyampaikan bahwa setiap tiga bulan sekali diadakan rapat komite di sekolah.

"iya mas setiap tiga bulan sekali biasanya sekolah mengadakan rapat dengan komite" (KK/23-12-18)

Berdasarkan hasil observasi yang dilakukan oleh peneliti pada tanggal 8 dan 9 Desember 2018 dalam upaya untuk menciptakan suasan belajar yang nyamanpihak sekolah dan orangtua melaksaanakan kerjabakti bersama yang meliputi pengecatan dinding-dinding kelas, meja dan kursi, serta membersihkan lingkungan sekolah.

Kegiatan yang juga dilaksanakan bersama dengan orangtua adalah kegiatan pengajian pada setiap jumat legi yang di ikuti oleh guru, siswa, orangtua dimana tujuan dari diadakannya pengajian jumat legi adalah menumbuhkan karakter pada 
siswa yang meliputi kemandirian, gotong royong, dan penanaman nilai keagamaan di dalamnya. hal tersebut sesuai penuturan kepala sekolah.

"Setiap jumat legi istighosah, dzikir, doa tiap jumat legi. unggulan jumat legi itu kan dalam rangka ya bisa menumbuhakn semua karakter disitu, ada mandiri, ada gotong royong karena pada saat pelaksanaannya muncul kerjasama itu gitu lho, terutama juga di religiusnya" (KS/1-12-18).

Berdasarkan hasil observasi yang dilakukan oleh peneliti pada tanggal 7 Desember 2018 kegiatan pengajian jumat legi diikuti oleh siswa, guru, dan orangtua. Sebelum kegiatan dimulai semua persiapan kegiatan disiapkan bersama-sama terurama oleh murid sehingga tujuan utama dalam mengembangkan karakter dapat tercapai serta dengan adanya kegiatan pengajian jumat legi ini dapat menjalin komunikasi yang baik antara pihak sekolah dengan orangtua.

Pendekatan yang dilakukan oleh kepala sekolah dalam upaya untuk menjalin komunikasi dan rasa percaya oleh masyarakat dilingkungan sekolah dan orang tua siswa adalah dengan selalu mengikuti kegiatan pengajian yang diselenggarakan oleh warga desa di sekitar sekolah. Di sela-sela pengajian tersebut kepala sekolah diberikan kesempatan untuk menyampaikan perkembangan maupun kendala yang ada di sekolah. Selain dengan mengikuti pengajian kepala sekolah juga sering melakukan kunjungan kerumah komite untuk menyampaikan permasalahan dan programprogram kegiatan yang ada di sekolah. Hal tersebut sesuai dengan penuturan kepala sekolah.

"Pendekatan yang tidak formal kadang-kadang berkunjung kerumahnya komite untuk menyampaikan apa permasalahan kita kan gitu, jadi ya kita berkunjung, kemudian ya terutama paguyupan-paguyupan itu memang kita rangkul kita benar-benar dekat dengan mereka dari apa, untuk kegiatan apapun kita mengkomunikasikan dengan komite dan paguyupan karenakan penggeraknya itu. saya juga ikut kegiatan yasinan setiap hari kamis di kampong. jadinyakan saya diberi waktu untuk ngomong bagaimana mengenai sekolah disini kan saya ada kesempatan jadi saya menyampaikan ya ndak ada terjadi miskomunikasi antara sekolah dengan masyarakat” (KS/1-12-18).

Penuturan serupa juga disampaikan oleh orang tua yang peneliti wawancarai bahwa kepala sekolah ikut serta dalam kegiatan pengajian yang diselenggarakan oleh warga sekitar sekolah.

"Iya mas Bu Sul kadang ikut pengajian bareng sama ibu-ibu yang lain”(OT1/1-12-18).

“Iya mas ikut pengajian ibuknya”(OT2/1-12-18). 


\section{Peran Serta Orang Tua dalam Peningkatan Mutu Sekolah}

Bentuk-bentuk partisipasi dari masyarakat menurut Choresyo (2017) dibagi menjadi 5 bentuk partisipasi, yaitu (1) Partisipasi buah pikiran, (2) Partisipasi keterampilan, (3) Partisipasi tenaga, (4) Partisipasi uang, dan (5) Partisipasi harta benda

Bentuk-bentuk partisipasi dari masyarakat maupun orangtua di SDN Songgokerto 3 Kota Batu antara lain berupa finansial, pemikiran, barang, keterampilan. hal tersebut sesuai dengan penuturan kepala sekolah.

"bentuk partisipasi dari orang tua ya tenaga, pikiran, ya finansial, ada ya bisa berupa barang berupa uang, tapi yang mengkordinir bukan sekolah langsung dari komitenya "(KS/1-12-18).

Penuturan serupa juga disampaikan oleh ketua komite dimana bentuk partisipasi dari orangtua kepada sekolah berupa uang, ide dalam mengembangkan kegiatan sekolah, dan tenaga.

"Orang-orang biasanya kerja bakti di sekolah bareng-bareng seperti minggu kemarin mas kerja bakti bareng-bareng disekolah, biasanya pas kerjabakti misal ada yang perlu diperbaiki butuh biaya orang-orang rembukan urunan berapa gitu"(KK/23-12-18)

Bentuk partisipasi dari masyarakat maupun orang tua di SDN Songgokerto 3 Kota Batu berupa uang dan tenaga salah satunya adalah saat kegiatan kerja bakti untuk memperbaiki saluran air yang berada di belakang sekolah agar tidak banjir ketika musim hujan. Pada saat kerja bakti untuk memperbaiki gorong-gorong tersebut terdapat salah satu orang tua menyampaikan kepada kepala sekolah untuk memasang gorong-gorong agar tidak banjir kembali. Karena terbatasnya anggaran, kepala sekolah menyampaikan bahwa tidak ada anggaran untuk memasang goronggorong, namun perwakilan dari orang tua tersebut menyampaikan bahwa masyarakat juga memiliki tanggung jawab akan hal tersebut. Sehingga dengan adanya kejadian tersebut orang tua mengadakan penggalaangan dana untuk perbaikan gorong-gorong yang ada di sekolah. hal tersebut sesuai dengan penuturan kepala sekolah.

"satu bulan saya disini itu walimurid sudah membetukan gorong-gorong ini sepanjang kurang lebih 50 meter itu dengan biaya suadaya karena sejak awalnya disitu banjir terus saya undang untuk kerja bakti"(KS/1-12-18). 
Bentuk partisipasi yang lain dari orang tua di SDN Songgokerto 3 Kota Batu adalah berupa keterampilan dimana terdapat orang tua yang memiliki usaha keripik dan sirup. Orang tua yang memiliki usaha keripik tersebut menjadi narasumber untuk mengajarkan bagaimana cara membuat keripik. Selain itu terdapat juga orang tua yang memiliki keahlian melukis dimana orang tua tersebut membantu untuk melukis dinding yang berada di sekolah (Gambar.3) agar suasana sekolah menjadi berwarna dan membuat suasana sekolah menjadi menyenangkan. Hal tersebut sesuai dengan penuturan kepala sekolah dan hasil observasi.

"Oh iya ada keahlian sebagai narasumber membuat sirup terus keripik, anakanak diajari bagimana membuat keripik" (KS/1-12-18).

Berdasarkan observasi yang dilakukan oleh peneliti pada tanggal 8 Desember 2018 bentuk partisipasi keahlian yang lain dari orangtua pada sekolah adalah partisipasi keahlian melukis. Pada saat kegaitan kerja bakti bersama terdapat beberapa orangtua yang memiliki keahlian melukis, melukis dinding-dinding yang ada disekitar sekolah untuk memberikan kesan berwarna dan ceria. Harapan dari dilukisnya dinding-dinding disekitar sekolah adalah dapat membuat siswa menjadi nyaman berada di sekolah.

Bentuk partisipasi lain yang dilakukan oleh orangtua adalah bentuk partisipasi berupa barang. Partisipasi berupa barang yang diberikan oleh orangtua berdasarkan hasil wawancara dengan kepala sekolah adalah melengkapi atau memperbaiki fasilitas yang sudah ada seperti menyumbang berupa semen untuk membangun dan pintupintu yang sudah rusak dan perlu untuk di perbaiki. Hal tersebut sesuai dengan penuturan kepala sekolah

“ Komite saya kalau akhir tahun itu kesini, bu saya mau bersihkan sekolah ini, aku gak duwe duek $i$, dikomite ada. Jadi ngganti pintu kadang ngganti pintu jeding. jutul ada yang semen tiga sak"'(KS/1-12-18).

\section{E. PEMBAHASAN}

Kebijakan yang diterapkan oleh kepala sekolah dalam mengikutsertakan orangtua dalam setiap program yang ada di sekolah tergolong efektif. Hal tersebut sesuai dengan teori kebijakan yang dikemukakan oleh Grindle (1980) dimana suatu kebijakan keberhasilannya dapat diukur dari proses pencapaian dan hasil.

Dilihat pada proses yang dapat dinilai dari aksi kebijakannya, SDN Songgokerto 3 Kota Batu telah konsisten dalam menerapkan kebijakan tersebut. 
Setiap kegiatan yang ada di sekolah selalu di komunikasikan dengan orang tua dan terdapat program rutin yang melibatkan partisipasi orangtua yaitu pengajian setiap jumat legi.

Dilihat dari tujuan kebijakan yang dapat diukur melalui efek dari masyarakat dan tingkat perubahan yang terjadi saat ini orang tua lebih peka terhadap apa yang terjadi di sekolah, dari pihak sekolah menyampaikan suatu kendala kepada orang tua, dan orangtua segera tanggap dalam membantu menyelesaikan kendala yang terjadi di sekolah. Perubahan positif yang terjadi di SDN Songgokerto 3 Kota Batu saat ini adalah menerima penghargaan sekolah Adiwiyata pada tingkat Jawa Timur yang hal tersebut tidak terlepas dari adanya partisipasi orangtua.

Mengacu pada bentuk-bentuk partisipasi yang sudah dilakukan oleh orangtua yang meliputi partisipasi dalam bentuk tenaga, pemikiran, uang, barang, dan keahlian tidak semua bentuk partisipasi berjalan dengan seimbang, terdapat partisipasi yang tinggi dan ada yang cenderung lebih rendah dari yang lain. Tidak keseimbangan jenisjenis partisipasi yang dilakukan oleh orang tua dipengaruhi oleh banyak faktor yang mempegaruhi bentuk partisipasi dari orangtua. menurut Westra (2007) terdapat beberapa hal yang mempengaruhi tingkat keberhasilan dari partisipasi yaitu: 1) Kesempatan ikut berpartisipasi sebelum suatu kegiatan dimulai, 2) Biaya untuk ikut berpartisipasi tidak lebih dari nilai-nilai ekonomi, 3) Subjek partisipasi sesuai dengan orang yang akan berpartisipasi, 4) Orang yang berpartisipasi memiliki kemampuan khusus seperti pengetahuan dan kecerdasan, 5) Orang yang akan berpartisipasi memiliki kemampuan saling berkomunikasi dengan baik, 6) Tidak ada satu kelompok yang merasa terancam, 7) Memiliki kebebasan bekerja yang luas, 8) Adanya keterikatan sesame anggota untuk tercapainya tujuan yang ingin di capai.

Upaya yang sudah dilakukan oleh sekolah untuk mengikut sertakan orang tua disetiap program kegiatan yang ada di sekolah untuk tercapainya pendidikan yang bermutu di SDN Songgokerto 3 Kota Batu sesuai dengan penelitian yang dilakukan oleh Wahyudi (2016) dimana orang tua memiliki peran yang penting dalam mengambangkan program kegiatan yang terdapat di sekolah. Sejalan dengan penelitian yang dilakukan oleh Wahyudi (2016), penelitian yang dilakukan oleh Sinaga (2017) menunjukkan terdapat hubungan yang positif antara keterlibatan komite dengan peningkatan mutu pendidikan yang ada di sekolah. Semakin tinggi 
keterlibatan orang tua dalam setiap program di sekolah maka semakin tinggi pula mutu pendidikan.

Bentuk komunikasi yang dilakukan oleh kepala sekolah SDN Songgokerto 3 Kota Batu yang menyampaikan suatu program ataupun permasalahan yang tengah terjadi di sekolah dengan mengadakan rapat setiap tiga bulan sekali ataupun menyampaikan pada saat ada suatu pengajian di rumah salah satu orang tua menurut Lestari \& Nurhayat (2015) masuk pada kategori komunikasi kelompok dimana komunikasi kelompok merupakan suatu bentuk interaksi secara tatap muka yang memiliki suatu tujuan seperti berbagi informasi, memecahkan suatu permasalahan.

Penerapan teknik komunikasi yang telah diterapkan oleh kepala sekolah SDN Songgokerto 3 Kota Batu efektif sehingga masyarakat dan orang tua dapat ikut terlibat dalam setiap kegiatan yang ada disekolah dan berpartisipasi baik berupa bentuk uang, tenaga, ataupun pikiran. Adanya komunikasi yang efektif tersebut berdampak pada tumbuhnya potensi sosial atau biasa dikenal dengan istilah modal sosial. Modal sosial merupakan segala sesuatu yang merujuk pada dimensi institusional, hubungan yang terbentuk, serta norma yang membentuk kualitas dan kuantitas hubungan sosial dalam masyarakat (Saefulrahman, 2015).

Terbentuknya modal sosial yang ada antara sekolah dengan masyarakat dan orang tua maka terbentuk pula: 1) Partisipasi dalam jaringan, maksudnya adalah modal sosial tidak terbentuk oleh satu orang saja, tetapi adanya kemampuan sekelompok individu yang terdapat dalam satu hubungan sosial dalam melibatkan dirinya sehingga terbentuk adanya suatu jaringan. 2) Resiprocity, tumbuhnya rasa ingin membantu dan mendahulukan kepentingan orang lain dan tidak mengharpakan balasan. 3) Kepercayaan, Sikap saling percaya dalam hal ini berarti masyarakat dan orang dengan sekolah untuk saling mendukung bahwa tidak ada yang merasa dirugikan 4) Tindakan yang proaktif, adanya keinginan yang kuat dari dalam diri individu untuk berpartisipasi dalam setiap kegiatan (Hasbullah, 2006). 


\section{F. KESIMPULAN}

1. Strategi yang diterapkan adalah dengan selalu ikut dalam setiap kegiatan yang diadakan oleh masyarakat di lingkungan sekolah atau orang tua dengan tujuan untuk menjalin silaturahmi dan terbentuknya komunikasi yang baik dengan masyarakat dan orangtua.

2. Bentuk partisipasi dari orang tua di SDN Songgokerto 3 Kota Batu berupa pemikiran seperti memberikan masukan-masukan dalam program kegiatan di sekolah, keterampilan seperti memberikan pelatihan pada siswa bagaimana cara membuat keripik, tenaga seperti dalam memperbaiki sarana prasarana pendukung proses belajar mengajar seperti memperbaiki kursi ataupun meja, uang, dan benda.

\section{G. SARAN}

Disarankan pada peneliti lain untuk melakukan penelitian di sekolah yang lain untuk mengetahui bagaimana strategi yang dilakukan oleh pihak sekolah untuk mengikutsertakan atau melibatkan orang tua ikut berperan secara aktif dalam setiap program kegiatan yang ada disekolah, serta mengetahui bentuk-bentuk partisipasi orang tua demi tercapainya pendidikan yang bermutu. 


\section{Daftar Rujukan}

Anggraeni, N. D., Yoto, \& Basuki. (2015). Studi Tentang Peran Serta Orang Tua dan

Dunia Usaha/Industri dalam Peningkatan Mutu Pendidikan di SMK Negeri 1 Singosari. Jurnal Teknik Mesin, (1), 11-20.

Arikunto, S. (2006). Prosedur Penelitian: Suatu Pendekatan Praktek. Jakarta: PT. Rineka Cipta.

Basri, M. (2011). Budaya Mutu Dalam Pelayanan Pendidikan. Jurnal Otoritas, I(2).

Choresyo, B., Nulhaqim, S. A., \& Wibowo, H. (2017). Partisipasi Masyarakat Dalam Pengembangan Kampung Qisata Kreatif Dago Pojok. Prosiding KS Riset \& PKM, 4(1), 60-79.

Edward, S. (2011). Total Quality Management in Education, manajemen Mutu Pendidikan. Jogjakarta: IRCISod

E. Mulyasa. (2002). Manajemen Berbasis Sekolah. Bandung: PT. Remaja Rosdakarya Falah, M. (2012). Masalah Pendidikan di Indonesia. Retrieved from http://republika.co.id/berita/jurnalisme-warga/wacana/12/12/10/mesymemasalah-pendidikan-di-indonesia

Grindle, M. S. (1980). Politics and Policy Implementation in The Third Word. New Jersey: Princeton University Press.

Hasbullah, J. (2006). Social Capital: Menuju Keunggulan Budaya Manusia Indonesia. Jakarta: MR-United Press.

Herispon. (2010). Profil Setengah Pemimpin Serta Dampaknya Dalam Manajemen. Eko \& Bisnis, 1(1).

Kurniasih, W. D., \& Radiana, U. (2013). Pengembangan budaya mutu di sekolah dasar swasta bruder melati kota pontianak, 1-16.

Lestari, Y., \& Nurhayat, I. (2015). Strategi Komunikasi Sosialisasi Pengetahuan Dasar Komprehensif Hiv / Aids. Komunikasi, 9(2), 13-27.

Miles, M. ., \& A.M, H. (1984). Analisis Data Kualitatif. Jakarta: Universitas Indonesia.

Moleong, L. (2013). Metodologi Penelitian Kualitatif. Bandung: PT. Remaja Rosda Karya.

Peraturan Pemerintah No. 39 Tahun 1992 Tentang Peran Serta Masyarakat dam Pendidikan Nasional

Peraturan Pemerintah No.17 Tahun 2010 Tentang Pengelolaan dan Penyelenggaraan 
Pendidikan

Peraturan Pemerintah No. 32 Tahun 2013 Tentang Standar Nasional Pendidikan

Raraswati, P. (2016). Makalah Kebijakan Pembinaan Pendidikan Keluarga. Kementerian Pendidikan dan Kebudayaan, Direktorat Jendral PAUD dan PENMAS, PP-PAUD dan DIKMAS Jawa Barat.

Rohmah, S. (2016). Kurangnya Kesadaran Masyarakat Dalam Pendidikan. Retrieved from www.rakyatpos.com/kurangnya-kesadaran-masyarakat-dalampendidikan.html/

Saefulrahman, I. (2015). Kepemimpinan, Modal Sosial, dan Pembangunan Desa. Jurnal Ilmu Pemerintahan, 1(1), 149-166.

Saifulloh, M., Muhibbin, Z., \& Hermanto. (2012). Strategi Peningkatan Mutu Pendidikan di Sekola. Jurnal Sosial Humaniora, 5(2), 206-218.

Sallis. E. (2003). Total Quality Management in Education. London: Coghan Page Education Managemengt Series

Sani, R. A., Pramuniati, I., \& Mucktiany, A. (2015). Penjaminan Mutu Sekolah. Jakarta: PT. Bumi Aksara.

Sinaga, D. (2017). Analisa Peran Komite Sekolah dala Peningkatan Mutu Pendidikan di KEcamaran balige Kabupaten TOba Samosir (Studi Komparatif SMA Negeri 1 Balige dan SMA Negeri 2 Balige). Sosiohumaniora, 19(2), 159-166.

Sugiyono. (2013). Metode Penelitian Pendidikan (Pendekatan Kuantitatif, Kualitatif, dan $R \& D)$. Bandung: Alfabeta.

Uamedi. (2004). Manajemen Mutu Berbasis Sekolah/Madrasah (MMBS/M). Jakarta: CEQM.

Ulfatin, N. (2013). Metode Penelitian Kualitatif di Bidang Pendidikan: Teori dan Aplikasinya. Malang: Bayumedia Publishing.

Umar, M. (2015). Peranan Orang Tua Dalam Peningkatan Prestasi Belajar Anak. Jurnal Ilmiah Edukasi, 1(1), 20-28.

Usman, H. (2003). Metodologi Penelitian Sosial. Jakarta: Bumi Aksara.

Wahyudi, M. D. (2016). Implementasi manajemen Partisiapsi Orang Tua dalam Pendidikan Anak Usia Dini (PAUD) di Lembaga PAUD Mawaddah Banjarmasin. Jurnal Paradigma, 11(2), 33-40.

Wiersma, W. (1986). Research methods in education: an introduction. Massachusetts: Allyn and Bacon. 
Yanuarti, D., Jufri, A. W., \& Syuaib, M. Z. (2016). Kontribusi Partisipasi Orang Tua dan Kompetensi Sosial Guru Terhadap Mutu Pendidikan Di Sekolah Dasar Gugus 01 Kecamatan Ampenan Kota Mataram. Jurnal Ilmiah Profesi Pendidikan, 1(1).

Yanuartri, D., Jufri, A. W., \& Syuaib, M. Z. (2016). Kontribusi Partisipasi Orangtua Dan Kompetensi Sosial Guru Terhadap Mutu Pendidikan Di Sekolah Dasar Gugus 01 Kecamatan Ampenan Kota Mataram. Jurnal Ilmiah Profesi Pendidikan, 1(1), 99-112. 


\section{Lampiran}

\section{Transkrip Wawancara}

\section{A: Apa ada program yang melibatkan orangtua didalamnya?}

J: Ya setiap program sekolah selalu melibatkan orangtua seluruhnya, iya baik program pembelajaran, kemudian untuk kelengkapan sarpras, kegitan ektrakulikuler, semuanya melibatkan orangtua, jadi peran serta masyrakat mulai dari apaya melengkapi sarana prasarana yang tidak bisa dijangkau dengan dan BOS, baik BOSNAS ataupun BOSDA, kami komunikasi dengan Komite, komite mengkomikasikan dengan paguyupan dan orang tua. jadi penggalian danapun nnanti juda dari sana, ndak tau besarannya berapa tapi sekolah tidak merekomendasikan secara tertulis. Tapi untuk program program yang melibatkan masyarakat ya seperti pembenahan, kerja bakti, ya untuk menciptakan suasana sekolah yang bersih terutama adiwiyata itu juga ada hubungannya dengan walimurid, tiap tiga bulan sekali ada kerja bakti kemudian ada juga rapat komite juga tiga bulan sekali, kemudian kegiatankegiatan yang sifatnya apa ya memperingati hari besar agama yang sekiranya tidak bisa di cover oleh sekolah ya kerjasama dengan orang tua. Seperti latihan manasik haji setiap tahunkan? tiap tahun itu melibatkan komite, paguyupan, orang tua, kemudian TK Kusuma Pertiwi, PAUD Arumdalu, itu semua kita libatkan disini. jadi itu memang sudah ada programnya.

\section{A: Untuk Komunikasinya dengan orang tua atau komite itu bu bagaimana?}

J: Ya itu tadi ada rapat itu tadi ada rapat kadang-kadang kalau tidak formal kita juga ada saling pendekatan, ya kita berkunjung kerumahnya komite untuk menyampaikan apa permasalahan kita kan gitu, jadi ya kita berkunjung, kemudian ya terutama paguyupan-paguyupan itu memang kita rangkul kita benar-benar dekat dengan mereka dari apa, untuk kegiatan apapun kita mengkomunikasikan dengan komite dan paguyupan karenakan penggeraknya itu.

\section{A: Untuk bentuk partisipasi dari komite dan walimurid bagaimana?}

J: bentuknya? Ya tenaga, pikiran, ya finansial, ada ya bisa berupa barang berupa uang, tapi yang mengkordinir bukan sekolah (A: Langsung dari) langsung dari e komitenya langsung, jadiperuntukannya secara periodic juga dilaporkan kepada seluruh wali murid. biasanya pada saat penerimaan rapor semester 1 semester 2 biasanya di buat juga laporan tentang keuangan mereka. (A: Jadi dibedakan gitu ya 
bu pelaporan Uangnya?) jadi ya pelaporannya itu khusus yang diperoleh dari peran serta wali murid itu disampaikan, kalau yang dari kita biasanya awal tahun kita sampaikan tentang kondisi keuangan sekolah itu saya sampaikan sehingga ada pilahpilahnya seandainya biaya dari BOSNAS dan BOSDA ndak cukup orang tua tau, wali murid tau,

A: Kalau dari teori bentuk-bentuk partisipasi ada salah satunya keahlian, apa ada wali murid yang menymbangkan dalam bentuk itu?

J: Ono nggak bu sing alhi opo ngunu? Oh iya ada keahlian terutama anu patung, sebagai narasumber biasanya, sebagai narasumber dalam apa ya, anak-anak itu tho lomba-lomba biasae. tapi kalau untuk tim ahli dalam apa pengembagangan sekolah khusus tidak ada, kita ndak punya. (A: maksudnya yang tadi ada wali murid yang ahli seperti patung tadi) oh iya keterampilan itu juga ada itu, terus buat apa sirup kan juga orang tua yang ngajari, terus keripik kita yang nganu itu juga ada, yang sebagai narasumber anak-anak diajari bagimana membuat keripik.

\section{A; Apa masuk di materi pembelajaran?}

J; ndak, tidak (A: jadi diluar) ya diluar.

\section{A: Apa ada program unggulan yang bersama orang tua?}

$\mathrm{J}$ : ya jumat legi itu unggulan saya, setiap jumat legi istighosah, dzikir, doa tiap jumat legi.Sebenarnya program unggulan disini itu yang e disamping jumat legi itu yang saya unggulkan adalah ektrakulikuler karena jumlah siswa yang 124 ini ektra saya kurang lebih 10 jadi apa ya kalau saya program unggulan itu sajane. ektrakulikuler merupakan program unggulan karena apa?maksuda saya biar anak-anak sini karena kondisi di apa ya secara akademiknya itu kurang maka perlu program yang bisa menunjang untuk mengambangkan kemampuan anak di bidang mungkin seni, mungkin olahraga, itu diwadahi disitu. kalau untuk unggulan jumat legi itu kan dalam rangka ya bisa menumbuhakn semua karakter disitu, ada mandiri, ada gotong royong karena pada saat pelaksanaannya muncul kerjasama itu gitu lho, terutama juga di religiusnya.

\section{A: Apa waktu ibu pertama kali kesini orangtuanya sudah mudah dikordinir?}

$\mathrm{J}$ : ya belum kan kita perlu apa ya paling tidak sosialisasi, perlu duduk bersama mau dikemanakan sekolah ini, mau dibentuk seperti apa sekolah ini kan harus satu visi. sehingga orantua itu mengerti arahnya mau dikemanakan jadi harus ada sosialisasi baru paling tidak kita membuktikan. jadi untuk memberikan kepercayaan terhadap 
walimurid itukan tidak mudah, ndak hanya sekedar wes mbak sampean percoyo nang aku kan enggak, jadi seiring berjalannya waktu ya mulai dari kedisiplinan anak masuknya, kalau saya sebelum kesini masuknya 07.30 kadang-kadang sampai jam 08.00 tapi setelah saya disini yam au tidak mau jam 07.00 harus sudah masuk, terus saya sendiri sudah datang itukan paling enggak memberikan apa ya keyakinan oh iyo yo iki kepala sekolah e jam yaene wes teko kok dan orang-orang tau bagaimana saya memaparkan pada saat itu ya saya tanting leng-lengan maksudnya lek e njenengan minta ibarate mangan rawon ya dengan hanya rawon dodo rawon ambek tempe karena dengan adanya BOSDA biayanya bisanya cukup di operasional itu misalnya, terus sing gak iso muluk-muluk sing liyo-liyo koyo ektra ya secukupnya saja ya njenengan monggo, saya ya lebih enak. tapi njenengan minta yang bagaimana? opo koyo nganglik? ya bisa saja seperti ngaglik tapi paling enggak njenengan iku lho peran e nang sekolah kudu melok-melok gak iso lek guru-guru tok kan gak bisa, sekolah kan gak bisa. harus paling enggak harus ada yang saling mendukung programnya harus saling mendukung. kemudian kita juda secara intern memperbaiki, memperbaiki kinerja guru, mulai dari kedisiplinanya dari bagaimana kita mengajar ke anak-anak kesungguhannya kerja keras itu harus. jadi dalam rangka apa? upaya untuk memberi keyakinan. ya Alhamdulillah berjalannya waktu e tapi sebernya komunikasisaya semenjak masuk disiniorang-orang sudah mudah diajak ngomong dalam artian langsung mendukung greget itu koyok e yang saya rasakan lho ya, sudah yak arena komunikasi itu jadi saya awal-awal tahun itu saya juga ikut kegiatan yasinan setiap hari kamis di kampong. jadinyakan saya diberi waktu untuk ngomong bagaimana mengenai sekolah disini kan saya ada kesempatan jadi saya menyampaikan ya ndak ada terjadi miskomunikasi antara sekolah dengan masyarakat, kan orang-orang itu kadang-kadang berani di belakang ya to? rasan-rasan tok tapi lek begitu kita dihadapi orangnya takut nah saya menghilangkan itu wali murid, saat rapat saya berikan kesempatan untuk bertanya ibarate wong perang ndek njero kono maro metu yowes enggak, sehingga mereka punya keyakinan oh iyo aku usul yo di trimo kok, punya kepercayaan diri oh ternyata aku male akhir e yo di akumulasi apa ya digapai. jadi ndak merasa apa ya kadang orang masuk kesekolahan seperti njenengan gini tadi masuk kan sudah berbagai macam persiapan mental to? itu adalah a ibaratnya generasi sek mahasiswa lho yo, opo maneh warga masyarakat sing wali murid yoto?kan mesti lek kate nang sekolah mesti mikir aku engkok yoopo yo? engkok 
metuk i guru iku kudu aduh yoopo lek guru e ngene-ngene kan seperti itu? engkok lek kepala sekolah e ngene yoopo yo kan sampean ae tadi dagdigdugdagdigdugkan? jangankan sampean, saya sendiri kalau masuk ke lembaga lain sudah beda lagi saya, sudah merasakan iyo yo aku engkok menemui guru iko ndek endi itu bingung maka itu kita welcome.itu salah satu apa ya paling enggak kita kepada guru-guru bu tulung lek ono tamu wali murid segera di sambut, segera di sambut kita jangan karena kita di sekolah trus mariingunu jaim kan enggak. makanya saya juga dekat dengan masyarakat sini karena awal-awal itu saya ikut jdai tahu rumahnya orang-orang pada saat kegiatan itu tahu. trus ada apa-apa yang ada di sekolah saya pesen lek njengan ada masukan jangan rasan-rasan. jadi itu kuncinya komunikasi, transparan itu yang penting itu. kalau kita sudah transparan mengenai apapun ya terutama dalam hal keuangan kita minta bantuan katakanlah ndak minta bantuan dalam bentuk uang tapi kita membicarakan tenang fakta yang ada di sekolah. contoh satu bulan saya disini itu walimurid sudah membetukan gorong-gorong ini sepanjang kurang lebih 50 meter itu dengan biaya suadaya karena sejak awalnya disitu banjir terus saya undang untuk kerja bakti pada saat kerjabakti kan saya sampaikan mosok aku sing katene macul yoknopo niki kulo mboten nggadah duit kulo tasek anyar ten meriki, akhirnya orangorang kerjabakti sehari, setelah di dalam kerja bakti orang muncul oh iyo iki kudu dipasangi gorong-gorong lek enggak iki engkok hancul maneh trus akhrinya orangnya lapor bu gimana ini lek di pasang gorong-gorong saya jawab la duek e opo aku ra due duwek aku sek anyar e ndek kene gak wani aku narik-narik, mboten pun niki tanggung jawab e masyarakat meriki, langsung dihalaman itu langusng orang tua rapat sudah rapat yoopo nggawe iki, oh iyo wes lek ngono minimal urunan e 50rb, iya monggo terserah saya ndak tanggung jawab lho, pun niku urusan kulo tapi njenengan saget nyiapkan proposalnya bu? bisa besok jadi, iya, untuk ke orang-orang mungkin masyarakat yang lain diberitau. akhirnya ya jutul i ada yang semen tiga sak ada yang uang ada yang kerja bakti lama itu seminggu kalau ndak salah, itu sudah dikerjakan itu saya baru satu bulan disini

\section{A: Apa sempat ada komplain dari orang tua mengenai tarikan-tarikan seperti tadi?}

J: Tidak ada, enggak ada karena saya ndak narik saya ndak minta bantuan uang yang mereka pokok e saya tau ini harus jadi, ndak tau sana urunan opo narik terserah, karena ndak apa ya yang penting ndak ada hitam diatas putih ndak ada tanda tangan 
ndak ada tok stempel saya itu, kan peran serta itu ndak hanya berupa uang a, kalau didalam BOS kan ndak hanya berupa uang, bantuan kataknlah minta bangunkan iki monggo, dan saya juga untuk memang ada anggapan dulu katanya disini sering narik sering narik gitu,narik-narik untuk apa tapi katanya untuk gazebo ternyata kok enggak nah itu sudah diluar saya sudah enggak itu. kan masing-masing pimpinan itu juga punya trik sendiri, lek iso orangtua memang sekarang ada jargon pendidikan gratis, ya to? kan sulit gak boleh bu la bu gratis kok, padahal kalau di cermati didalam BOS itu sendiri ada juknis bahwa kita bisa untuk peran serta masyarakat. la wujudnya karena ndak hanya berupa uang pokok e lek bantuan itu misal e satu bulan sekali jumlah e ditentukan ada tanda tangan saya ada stempel saya itu ndak boleh ndak bisa kena saya karena itu tadi pesan moral e pendidikan gratis. saya akan katakan ke orangtua lek pendidikan gratis njenengan kok milih nang MI lapo kok milih sing mbayar? milih ke ngaglik yang juga notabene sama dengan ini tapi biaya juga sama. ke Al-Irsyad, Al-Irsyadkan mbayar kenapa? kan njenengan cari mutu pelayanan yang baik, saya itu tho berusaha ingin mosok se sekolah sekecil ini ektranya banyak, kegiatannya banyak, kan gitu. engkok lek aku kurang duek e yo aku utangono aku yo bantuen mangkanya orang-orang gitu. Komite saya kalau akhir tahun itu kesini, bu saya mau bersihkan sekolah ini, aku gak duwe duek I dikomite ada. Jadi ngganti pintu kadang ngganti pintu jading . halaman ini yang lapangan itu juga komite. 


\section{Foto Kegiatan}

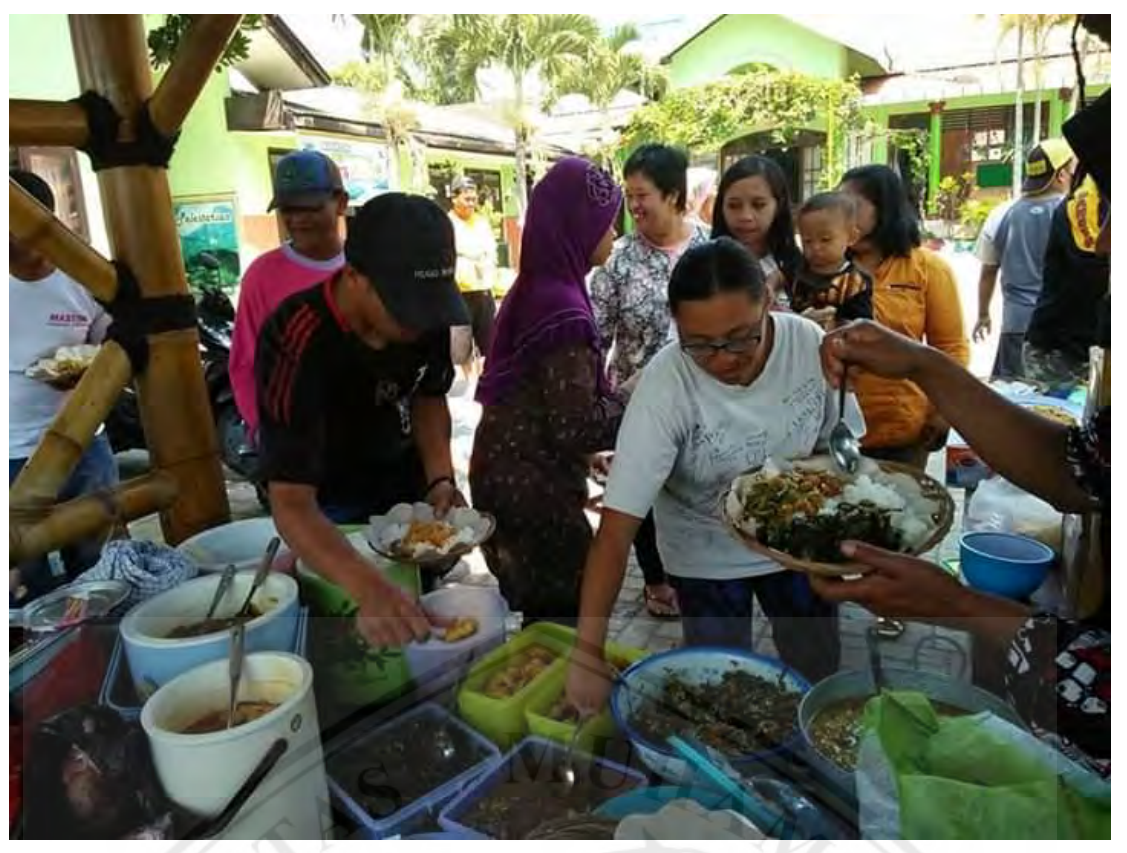

Foto 1: Makan Bersama Orang Tua Setelah Kerja Bakti

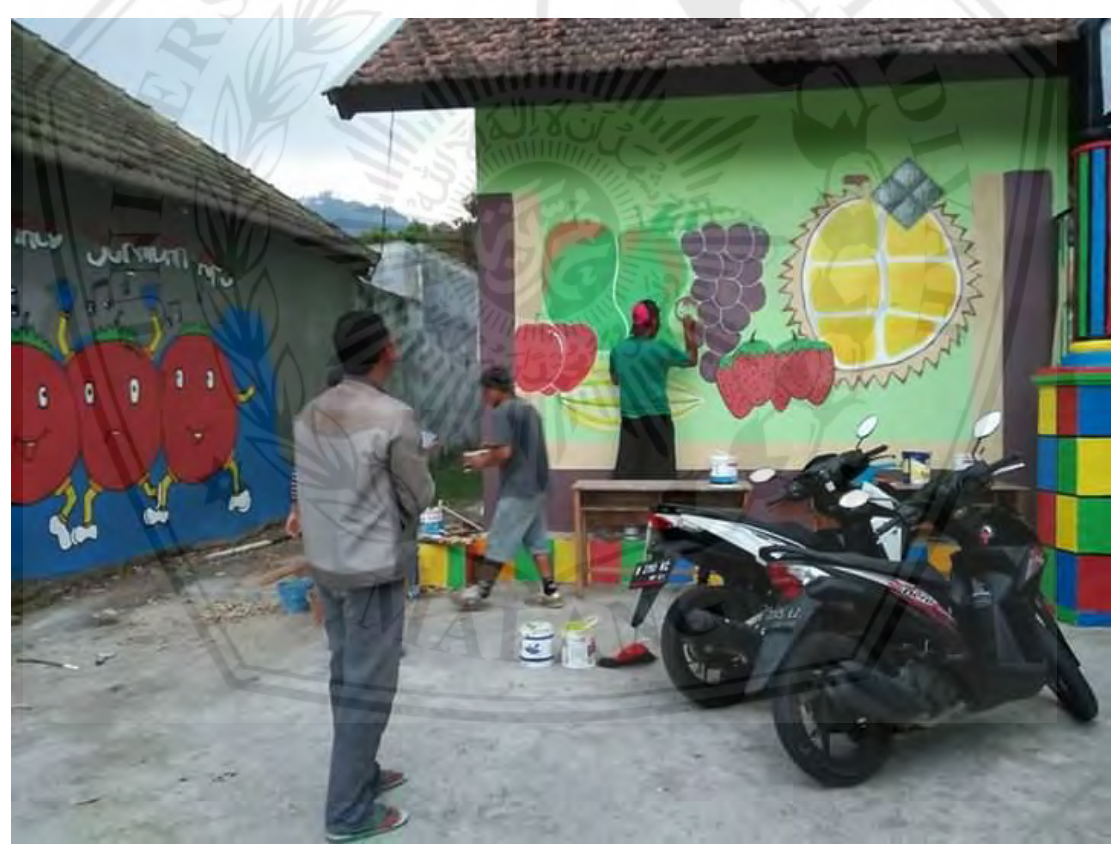

Foto 2: Orang Tua Melukis Dinding Sekolah 


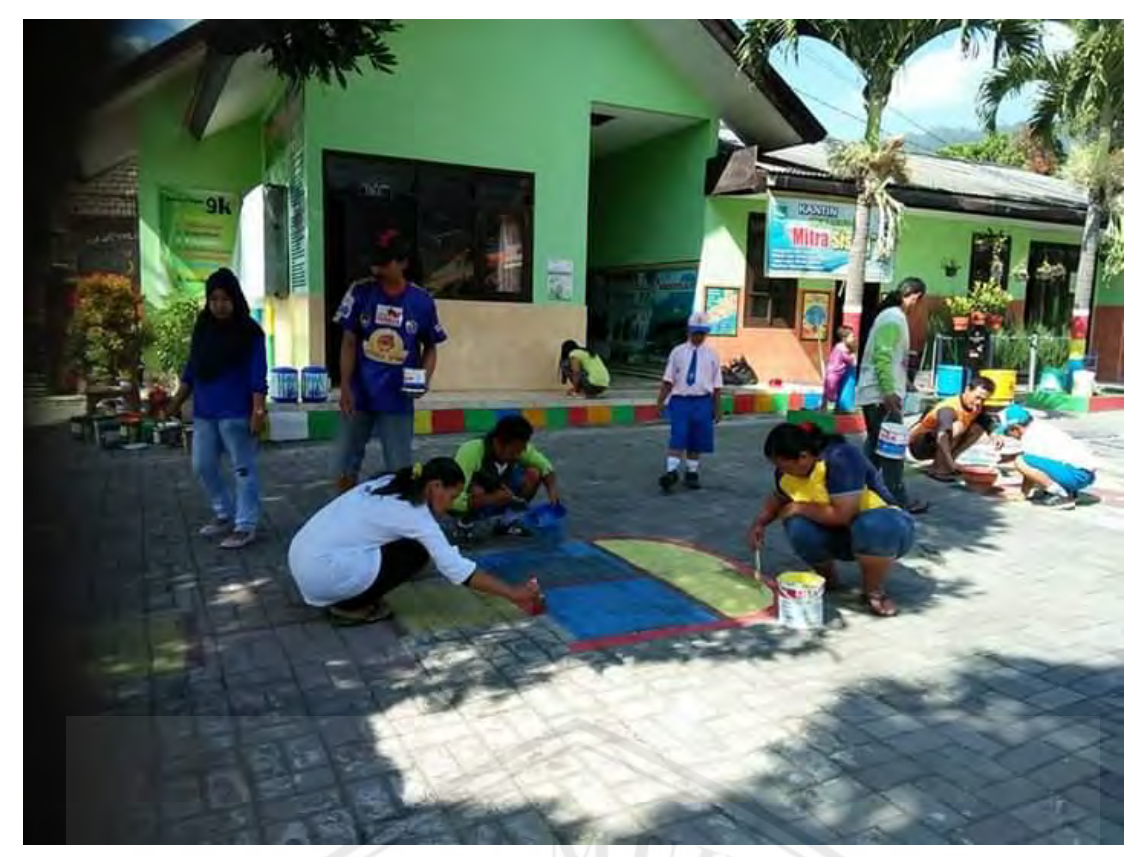

Foto 3: Orang Tua dan Siswa Mengecat Lapangan Sekolah

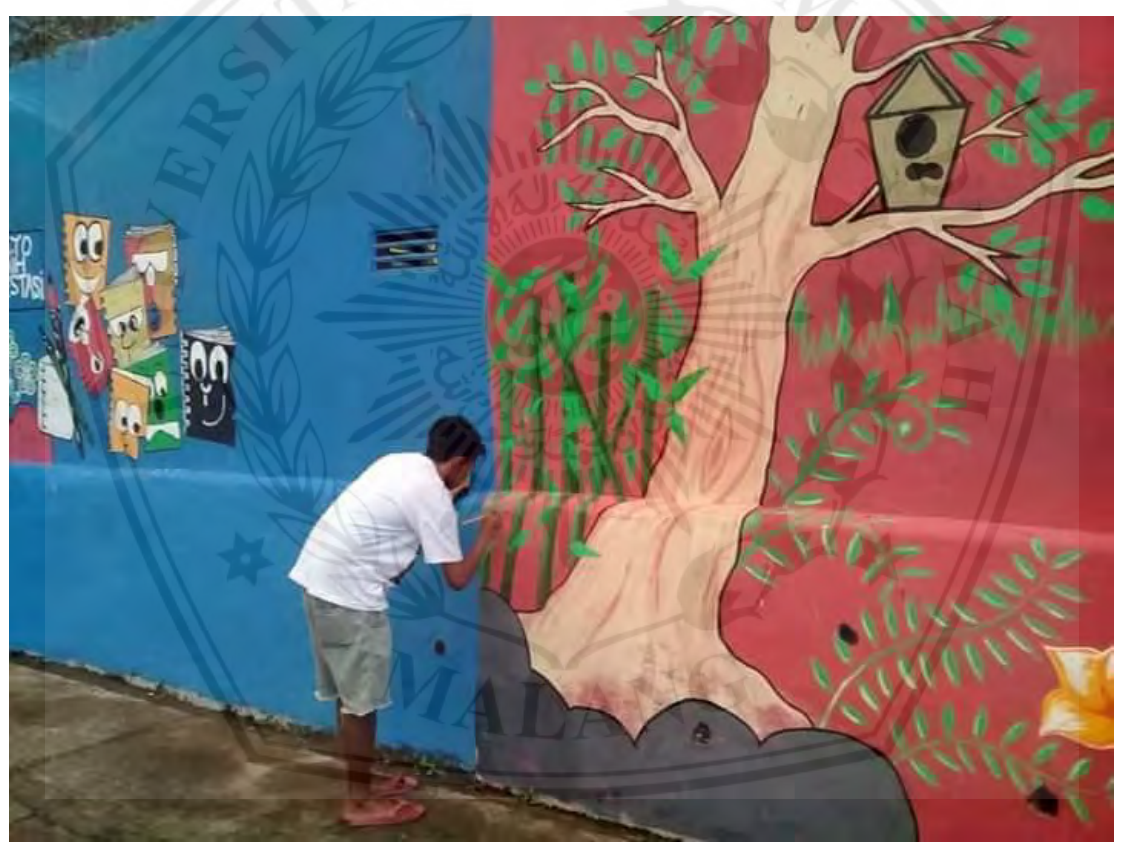

Foto 4: Orang Tua Melukis Dinding Sekolah 


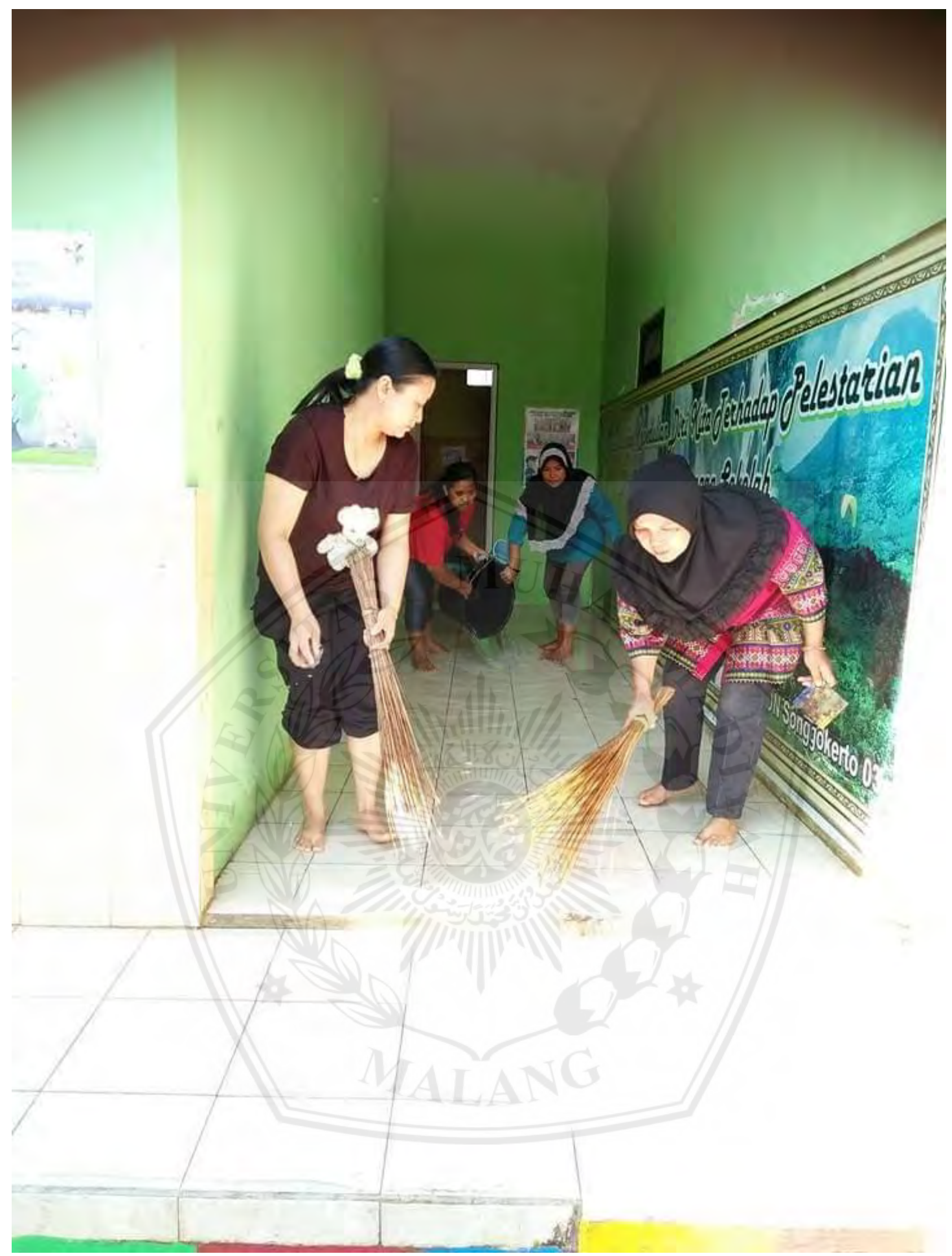

Foto 5: Orang Tua Kerja Bakti Membersihkan Lingkungan Sekolah 


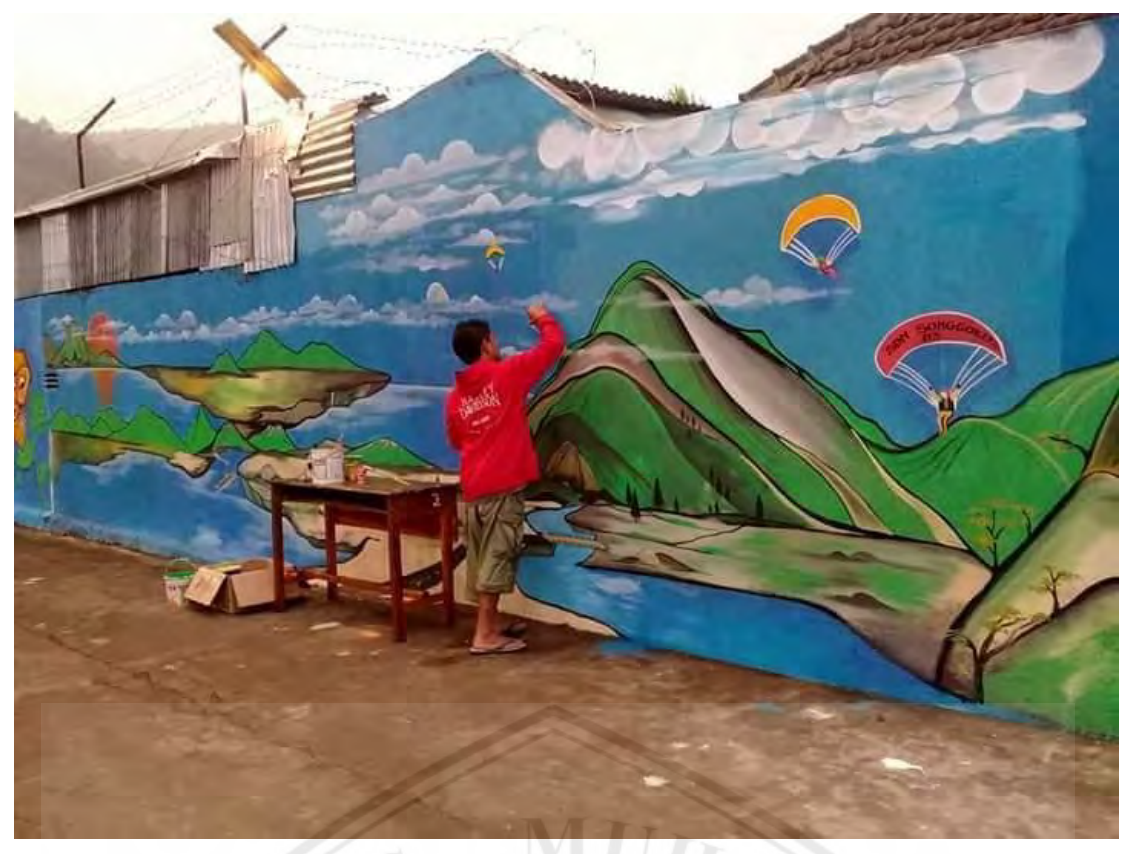

Foto 6: Orang Tua Melukis Dinding Sekolah

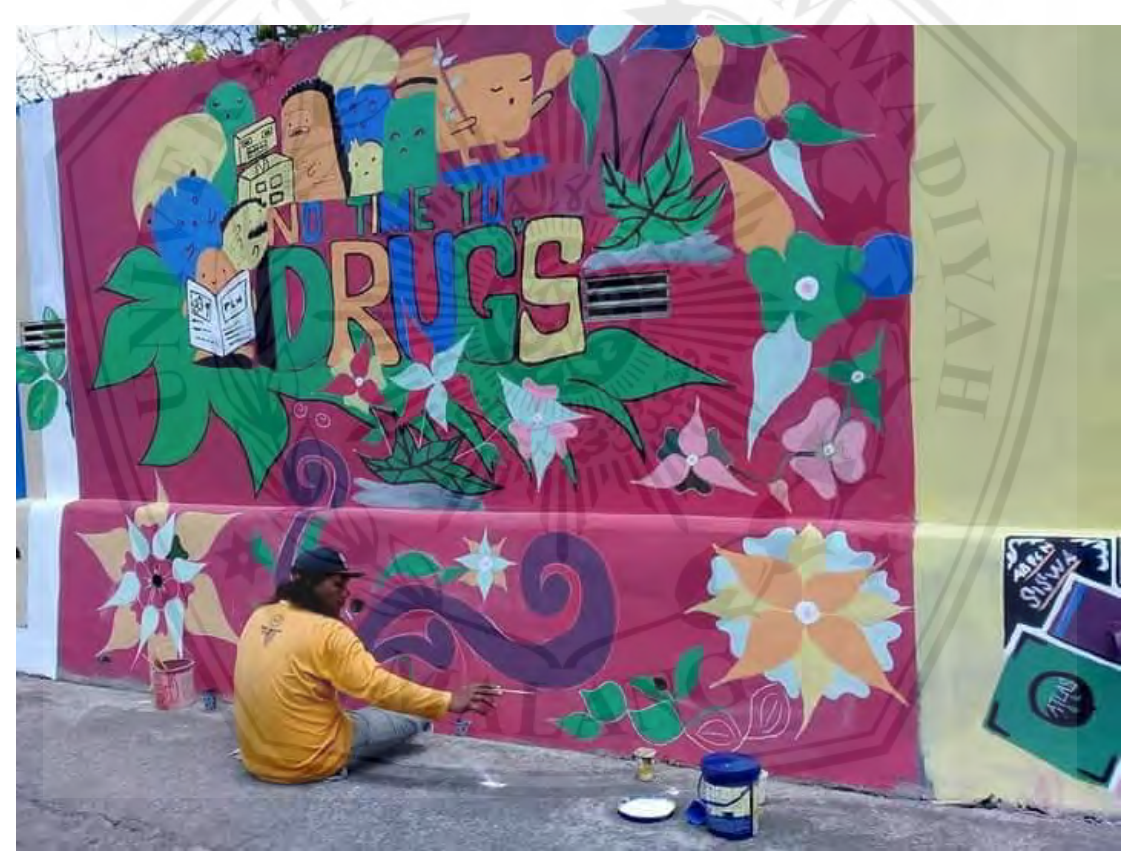

Foto 7: Orang Tua Melukis Dinding Sekolah 


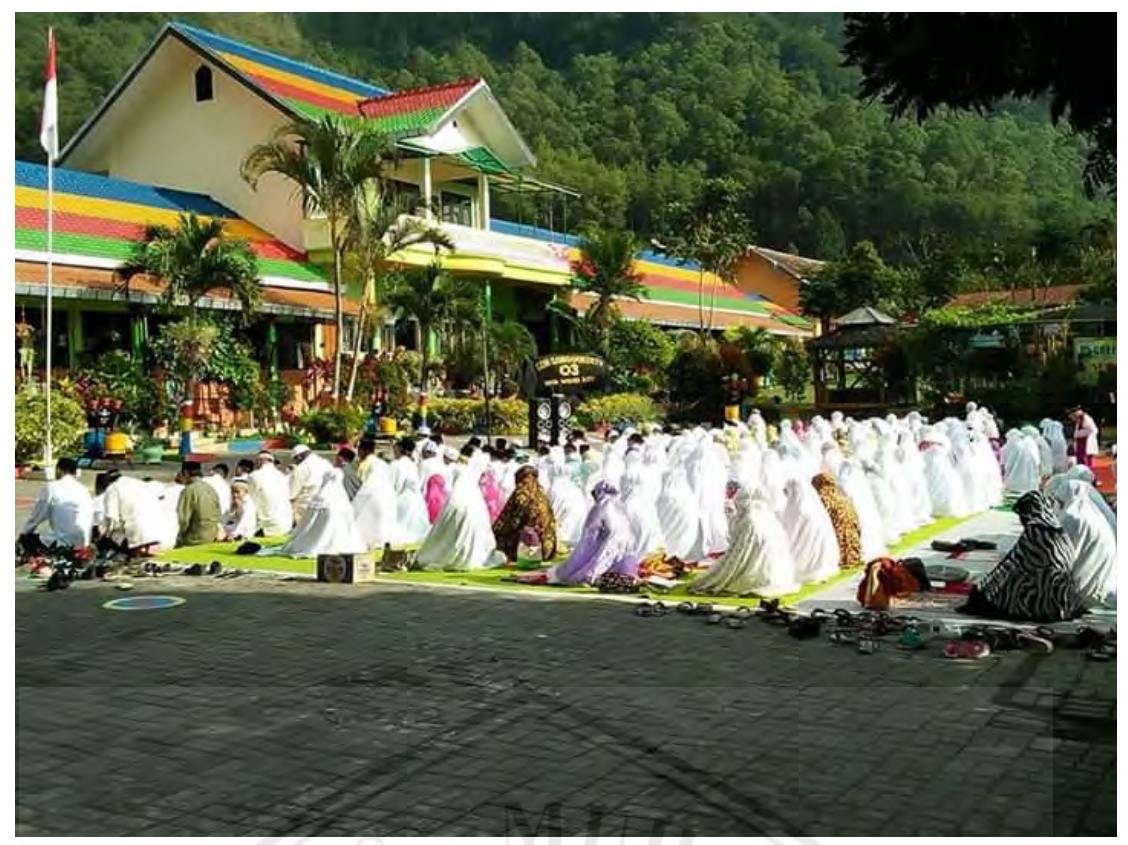

Foto 8: Kegiatan Pengajian Setiap hari Jumat Legi

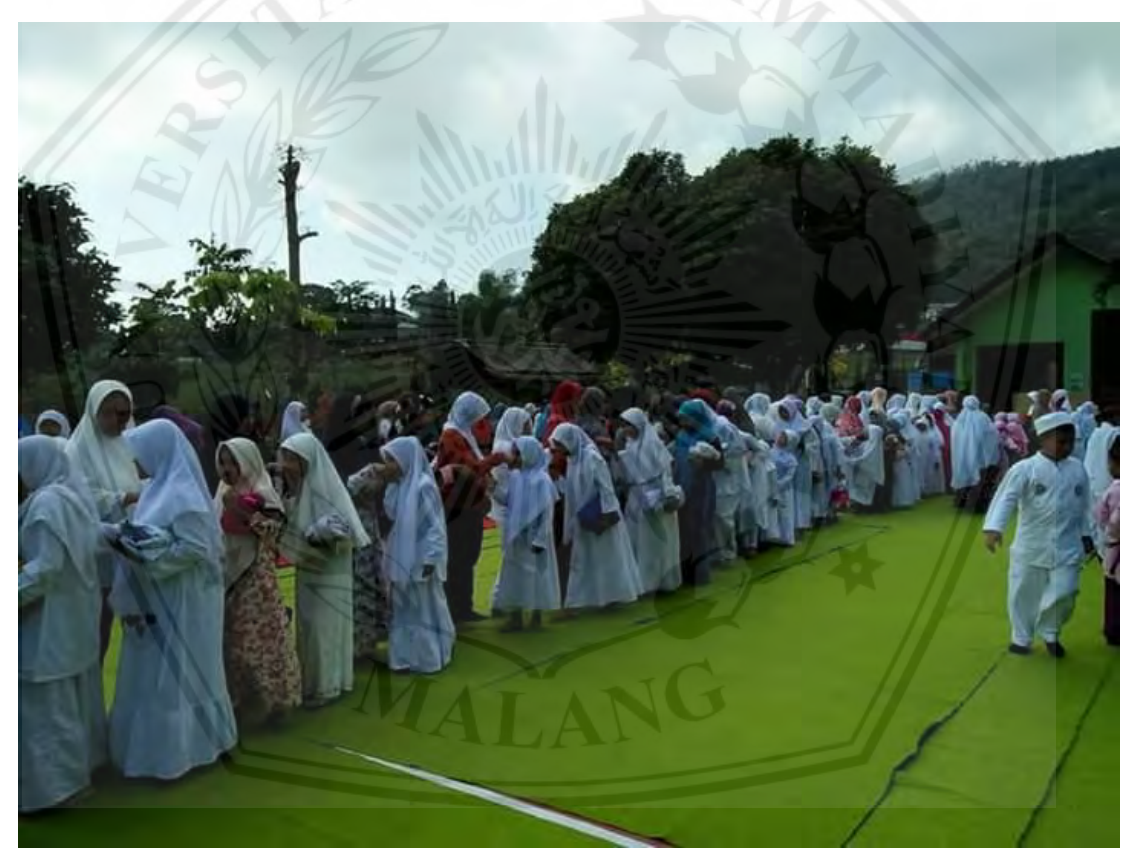

Foto 9: Kegiatan Pengajian Setiap hari Jumat Legi 